\title{
Dendritic Cells: Versatile Players in Renal Transplantation
}

\author{
Jinwen Lin ${ }^{1,2,3 \dagger}$, Hongyi Wang ${ }^{4 \dagger}$, Chenxi Liu ${ }^{4 \dagger}$, Ao Cheng ${ }^{4}$, Qingwei Deng ${ }^{4}$, Huijuan Zhu ${ }^{5}$ \\ and Jianghua Chen ${ }^{1,2,3 *}$
}

\begin{abstract}
${ }^{1}$ Kidney Disease Center, The First Affiliated Hospital, College of Medicine, Zhejiang University, Hangzhou, China, ${ }^{2}$ Key Laboratory of Kidney Disease Prevention and Control Technology, National Key Clinical Department of Kidney Disease, Institute of Nephrology, Zhejiang University, Hangzhou, China, ${ }^{3}$ The Third Grade Laboratory under the National State, Administration of Traditional Chinese Medicine, Hangzhou, China, ${ }^{4}$ Xiangya School of Medicine, Central South University, Changsha, China, ${ }^{5}$ Department of Pathology, The First Affiliated Hospital, College of Medicine, Zhejiang University, Hangzhou, China
\end{abstract}

\section{OPEN ACCESS}

Edited by:

Cheng Yang,

Fudan University, China

Reviewed by:

Helong Dai,

Central South University, China

Qi Cao,

Westmead Institute for Medical

Research, Australia

*Correspondence:

Jianghua Chen

chenjianghua@zju.edu.cn

${ }^{t}$ These authors have contributed equally to this work

Specialty section:

This article was submitted to Alloimmunity and Transplantation,

a section of the journal

Frontiers in Immunology

Received: 16 January 2021 Accepted: 22 April 2021

Published: 19 May 2021

Citation:

Lin J, Wang H, Liu C, Cheng A, Deng Q, Zhu H and Chen J (2021) Dendritic Cells: Versatile Players in Renal Transplantation.

Front. Immunol. 12:654540. doi: 10.3389/fimmu.2021.654540
Dendritic cells (DCs) induce and regulate adaptive immunity through migrating and maturing in the kidney. In this procedure, they can adopt different phenotypes rejection-associated DCs promote acute or chronic injury renal grafts while tolerogenic DCs suppress the overwhelmed inflammation preventing damage to renal functionality. All the subsets interact with effector $T$ cells and regulatory $T$ cells (Tregs) stimulated by the ischemia-reperfusion procedure, although the classification corresponding to different effects remains controversial. Thus, in this review, we discuss the origin, maturation, and pathological effects of DCs in the kidney. Then we summarize the roles of divergent DCs in renal transplantation: taking both positive and negative stages in ischemia-reperfusion injury (IRI), switching phenotypes to induce acute or chronic rejection, and orchestrating surface markers for allograft tolerance via alterations in metabolism. In conclusion, we prospect that multidimensional transcriptomic analysis will revolute researches on renal transplantation by addressing the elusive mononuclear phagocyte classification and providing a holistic view of DC ontogeny and subpopulations.

Keywords: dendritic cells, renal transplantation, rejection, tolerance, ischemic-reperfusion injury

\section{INTRODUCTION}

In all tissues, DCs function in a network of mononuclear phagocytes with many innate immune cells taking center stage (1). This network in the kidney is complex and heterogeneous, highly relying on macrophages and DCs (2). Discovered by Metchnikoff 150 years ago, macrophages can mediate fibrosis after renal transplantation, whereas DCs were first described in 1973 by Steinman and Cohn as even elongated or stellate cells to present antigens. Given that DCs and macrophages are both involved in innate immune networks, DCs should have overlapping functionalities as macrophages in tissue homeostasis, promoting pathogen defense and contributing to acute or chronic rejection $(2,3)$. But compared with macrophages, the unique roles of DCs in rejection or tolerance are still ambiguous and undefined partly because they often share similar surface markers (4-7). Equipped with increasingly available kidney biopsy data, the recent outbreak in the high-dimensional analysis of single-cell has sparked instructions for the classification of these immune cells (8-11). In this review, we first describe the consensus of DC ontogeny encompassing the origins, maturation, and pathological effects of DCs 
in the kidney. We then summarize the major roles of kidney DCs in three major aspects of renal transplantation, including ischemic injury when grafts are removed from the donors, rejection including acute and chronic process, and tolerance including induced or natural genic tolerance. Finally, we point out certain obstacles and disadvantages to prospect the value of multidimensional transcriptomic analysis.

\section{DC-LINKED PATHOLOGICAL PROCEDURE IN RENAL TRANSPLANTATION}

\section{The Origin and Migration of DCs in Kidney Allograft Rejection}

Like other tissues, dendritic cells in the kidney are derived from bone hematopoietic stem cells (Figure 1). Traditionally, cell surface markers were used to subdivide $\mathrm{CDCs}$ into $\mathrm{CDC1}$ and cDC2 (12). Human cDC1 mainly expressed CD11c, CD141, CLEC9A (C-type lectin domain family 9 member A) and highly expressed MHC (major histocompatibility complex) class II, while cDC2 mainly expressed CD11c, high- affinity Fc receptor for immunoglobin E, CD1c, CD1a and highly expressed CD11c and
MHC class II. CD11c, MHC class II, CD26, and interferonregulatory factor 8 (IRF8) are highly expressed in murine $\mathrm{cDC} 1$, and CLEC9A, XCR1, and CD103 are also expressed. In mice, cDC2 expresses high CD11c, MHC class II, CD11b, CD26, CX3CR1, interferon-regulatory factor 4 , dendritic cell inhibitory receptor 2 but expresses low IRF8 and F4/80 (Table 1).

Moreover, traditional DC subsets are described by lineagespecific transcription factors including DNA binding inhibitor 2 and interferon regulatory factor 4 . In mice, the conventional DC group 1 (cDC1) express neither SiglecH nor Ly6C, while the precursor of the conventional DC group 2 (cDC2) express no SiglecH but Ly6C (21). Based on these transcription factors, phagocytes expressing major histocompatibility complex (MHC) class II and integrin CD11c are named cDCs. Another independent subgroup, unconventional plasma-like dendritic cells, expressed transcription factor E2-2 and its myeloid antigen but did not express CD123. Whether they are related to traditional DC is still doubtable.

During circulation, the precursor dendritic cells develop and differentiate into kidney-specific dendritic cells (22). In the kidney, no more than $5 \%$ of dendritic cells are cDC1 expressing CD103; most DCs express CD11b and CX3CR1 and can be categorized into $\mathrm{CDC} 2$. Compared with dendritic cells in other parts of the body, kidney-specific dendritic cells can be

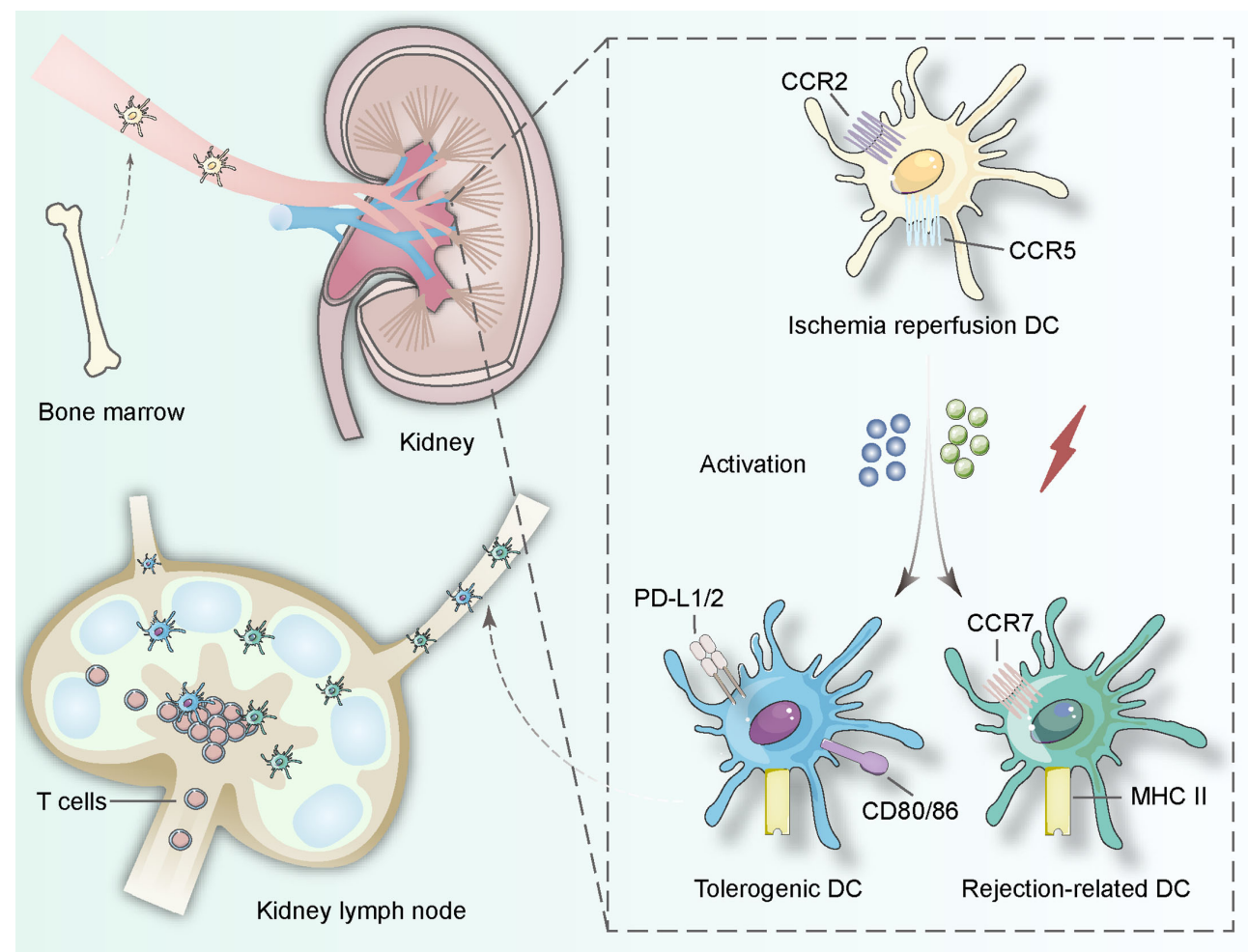

FIGURE 1 | DCs in the kidney originate from bone hematopoietic stem cells and involve in lymphatic recycling in vivo. When ischemia-reperfusion occurs, immature DCs start to search for interactions with T lymphocytes and change their surface proteins including CCR2, CCR5 to induce tolerance procedure (expressing PD-L1/2 and CD80/86) or rejection procedure (expressing CCR7 and MHC class II). The activation can be derived from pathogen-associated molecular patterns and dangerassociated molecular patterns in the procedure of ischemia-reperfusion. 
TABLE 1 | Remarkable features of three different types of DCs in renal transplantation.

\begin{tabular}{|c|c|c|c|}
\hline Clinical subsets & General functions & Key markers & References \\
\hline DCs in IRI & $\begin{array}{l}\text { Promotion of both inflammation and anti- } \\
\text { inflammation }\end{array}$ & $\begin{array}{l}\text { CD45, CD11c, MHC-II, TNF- } \alpha, \text { CD80, CD86, CD40, CD54, C1d, CD8 } \alpha \text {, but not } \\
\text { CD4 and CD205 }\end{array}$ & $(13,14)$ \\
\hline $\begin{array}{l}\text { Rejection-related } \\
\text { DCs }\end{array}$ & $\begin{array}{l}\text { Promoting acute rejection and chronic } \\
\text { rejection via different interaction with T cells }\end{array}$ & CD11c, MHC class II, CD1c, FCeRI & (15) \\
\hline Tolerogenic DCs & $\begin{array}{l}\text { Inducing anti-rejection effects via } \\
\text { suppressing various types of T cells and } \\
\text { activating Treg cells }\end{array}$ & $\begin{array}{l}\text { poor expression of MHC, T cell co-stimulatory molecules like CD40, CD80/86, } \\
\text { and T cell co-inhibitory ligands (e.g., programmed death ligand-1 and death- } \\
\text { inducing ligands) }\end{array}$ & $(16-20)$ \\
\hline
\end{tabular}

FCERI, high- affinity FC receptor for IgE; MHC, major histocompatibility complex.

located in the lymph nodes around the kidney and the kidney itself, which is essential for the control of adaptive immunity (23) (Figure 1). In the kidney, most of these phagocytes with the ability to activate $\mathrm{T}$ cells are located in the cortex. It can be confirmed that $\mathrm{CDC1}$ is located near the blood vessels, while most of these cells near the subcapsular and arterial connective tissue have the morphology of macrophages. The high osmotic pressure of transplanted medulla may inhibit the antigen presentation of DCS to $\mathrm{CD}^{+} \mathrm{T}$ cells, but the specific type of DCs still needs to be further studied.

Chemokines and corresponding receptors induce the migration of kidney-specific DCs. Chemokines are detected by receptors on the surface of precursor DCs and precursor DCs can migrate along the inverse chemical gradient pathway to the source. Receptor expression determines the specificity of kidney DCs. CX3CR1 and CCR2 are incorporated into the action of leaving the bone marrow, and CXCR4 helps precursor DCs retention in the marrow (24-26). But the inflammatory conditions after transplantation possibly alter the migration mechanism to mediate both rejection and tolerance, which remain unidentified and might be potential intervention sites in the future (Figure 1).

\section{The Maturation of DCs in Kidney Allograft Rejection}

With no stimuli, immature kidney DCs inhibit $\mathrm{T}$ and $\mathrm{B}$ lymphocytes, which also can coordinate tolerance (25). Danger-associated molecular patterns occur when ischemia and reperfusion happen, activating TLR4 (toll-like receptor 4) and leading to the maturation of DCs (27-29). This maturation induces inflammation and provokes adaptive immunity to specific antigens, such as alloantigen and so on $(30,31)$. According to Sporri and Reis e Sousa's report, dangerassociated molecular patterns (DAMPs) cannot make DCs promote T-helper responses, but exposure to pathogenassociated molecular patterns can (32). Taken together, DAMPs are not the most crucial pathway to activate DCs for allograft rejection (33-36). Furthermore, rejection can happen in T lymphocyte deficient conditions, implying that the maturation of DCs might be more than a complex mechanism triggered by DAMPs or pathogen-associated molecular patterns (37-40).

\section{The Possible Downstream Effects of DCs in Kidney Allograft Rejection}

Conventional hypothesis indicated donor DCs activate antidonor rejection via migration to the host second lymphoid nodes providing alloantigen to recipient $\mathrm{T}$ cells (41). This hypothesis resulted from observations on mouse models: $\mathrm{T}$ lymphocytes respond to antigen-presenting cells with non-selfMHC (major histocompatibility complex) in vivo $(42,43)$. Moreover, depleting leukocytes in the allografts drives longterm survival, whereas injecting donor DCs into the host restores acute rejection (44-49). Later research established that donor and recipient DCs play equal roles in mediating the rejection process, and recipient DCs are even more stable to present antigens. Deleting recipient DCs prolonged allograft survival significantly but depleting donor DCs did not (50). Also, DCs lacking MHC or CD80/86 molecules are killed by recipient natural killer cells during migration to the lymphoid nodes (50-53). Recently, donor DCs are viewed as transporters of antigen rather than presenters of antigen (54). MHC molecules can be exchanged between the donor and recipient DCs $(55,56)$. Therefore, recipient DCs gain non-self MHC from donor DCs, capable to activate $\mathrm{T}$ lymphocytes originated from recipients through both non-self MHC and self MHC (57-62).

The basic function of mouse $\mathrm{CDC1}$ is to use MHC class I molecules on its surface to extract antigens from $\mathrm{CD} 8^{+}$cytotoxic $\mathrm{T}$ cells and induce them to kill target cells. This plays a decisive role in the process of renal transplantation and may be directly related to cellular immunity. Also, mouse $\mathrm{CDC1}$ can induce regulatory $\mathrm{T}$ cells in lymphatic circulation $(63,64)$. The function of human $\mathrm{cDC1}$, which is different from that of mice, needs further study. However, compared with cDC1, cDC2 generally does not have the aforementioned antigen targeted by cytotoxic $\mathrm{T}$ cells (65-67). Therefore, in renal transplantation, cDC2 will not be killed by cytotoxic T cells but can induce B cells to respond through helper $\mathrm{T}$ cells, which may be the mechanism of antibody-mediated immune rejection (68). Finally, it has been revealed that $\mathrm{CDC} 2$ cells induce $\mathrm{T}$ helper cells to stimulate the production of pro-inflammatory mediators in the chronic renal inflammation model, so in the same chronic rejection, CDC2 may also be the center of inflammation and participate in the pathogenesis of immune effectors including antibodies.

\section{DCs IN IRI}

IRI happens frequently following renal transplantation via recruitment of immune cells including DCs by proinflammatory cytokines like tumor necrosis factor derived from hypoxic endothelial cells $(13,69)$ (Figure 2). The DCs involved in IRI have not been completely defined. Current studies tend to 


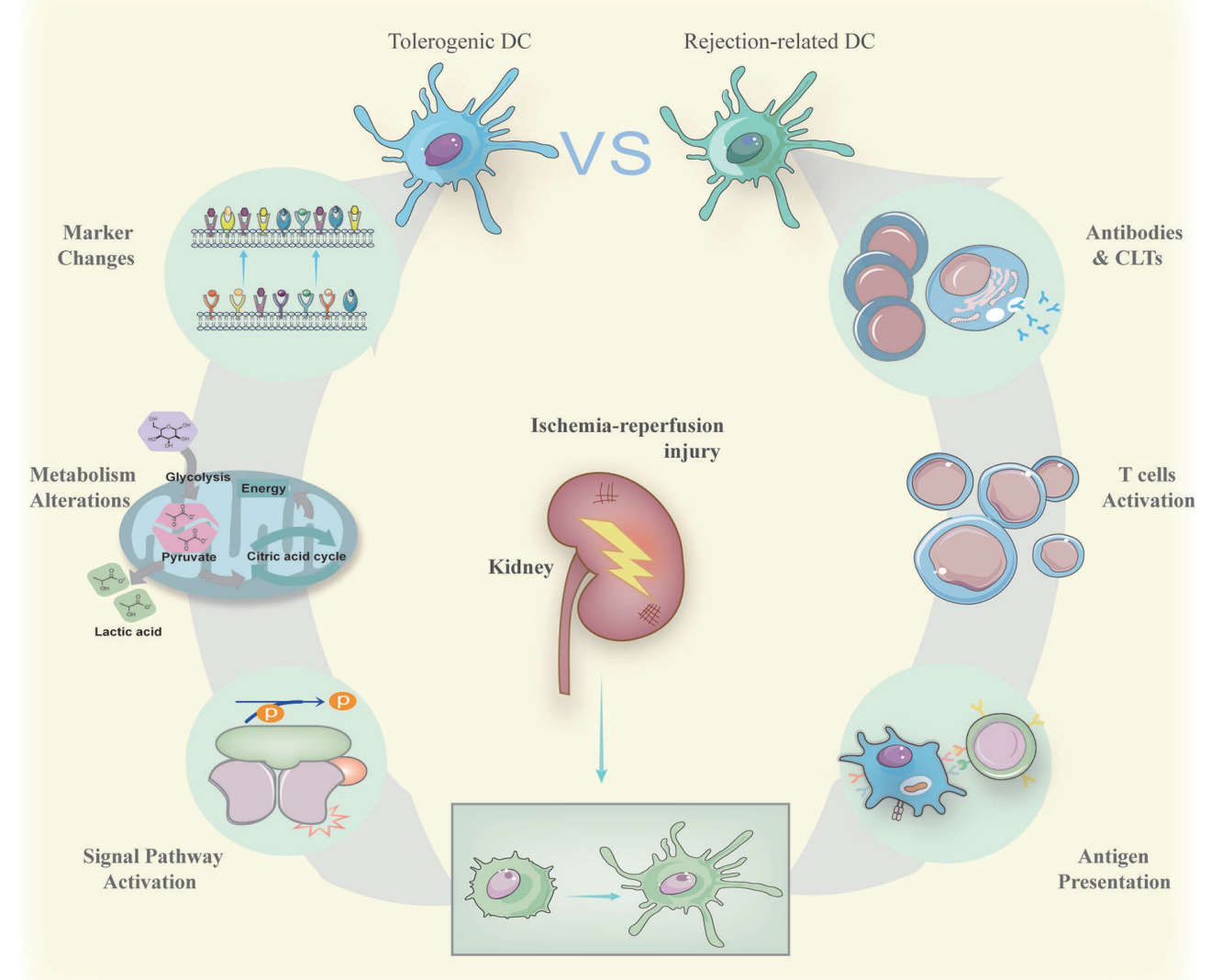

FIGURE 2 | Immature DCs can be activated by antigens derived from ischemia-reperfusion and act as the role of powerful antigen-presenting cells to trigger antibody-mediated rejection and cell-mediated rejection. The result of antibody-mediated rejection is activated B cell releasing harmful antibodies while active cytotoxic T cells kill donor cells forming cell-mediated rejection. On the contrary, when treated by specific drugs, immature DCs can also maintain their surface markers to suppress possible inflammation caused by transplantations via signal pathways activation regulating metabolism alterations. The signal pathways include $\mathrm{NF}-\kappa \mathrm{B}$ and $\mathrm{mTOR}$ summarized in the section The Generation of Tolerogenic DCs. The metabolism alterations involve glycometabolism and lipid metabolism with more details in the section The Generation of Tolerogenic DCs.

claim that DCs involved in IRI express CD45, CD11c, MHC-II, TNF- $\alpha$, CD80, CD86, CD40, CD54 (ICAM), C1d, CD8 $\alpha$, but not CD4 and CD205. All the markers might be useful in further investigations (Table 1). Then hypoxia-inducible factor $1 \alpha$ induces kidney DC maturation, damaging renal functionality (70-72). DCs can promote harmful activations of immune effects in vivo, but they are also associated with protecting renal function from IRI. Since immature DCs are less stimulatory than mature DCs, some researchers supposed that kidney DCs' role is to harm allograft (73-76). DCs feature in IL-10 as well as single Ig IL-1-related receptor, therefore, exhibiting the inhibiting effects on inflammation in IRI (77). On the contrary, immature kidney DCs can serve as an adverse player to mature DCs, preventing IRI (78, 79). Thrombin could release IL-12, IL-17, and C3a thus causing T helper-1 bias to influence kidney DCs' behaviors and determine the outcomes of IRI (80). High concentrations of tissue factors in the kidney may also contribute to IRI (81). Further studies are warranted to clarify the discrepancy about kidney DCs, especially the relationship between rejection-related DCs and tolerogenic DCs (Figure 2).

\section{REJECTION-RELATED DCs IN ALLOGRAFTS}

The traditional function of DCS is to mediate the rejection of harmful non-autogenous substances or abnormal autogenous materials, so the research on rejection-related DCs mostly employs traditional surface markers of cDCs. Although it is not recommended to judge the types of DCs based on only one surface marker, the comprehensive use of different surface markers can still accurately define rejection-related DCs (Table 1 for specific markers).

\section{Acute Rejection Based on the DC-Dependent Mechanism}

The interaction between DCs and T lymphocytes triggers a socalled acute rejection through the conventional pathway-donor DCs present alloantigen to recipient $\mathrm{T}$ cells directly $(82,83)$ (Figure 2). At first, the ischemia-reperfusion condition drives donor DCs to induce acute rejection (14). Secondly, active DCs search for immature or memory $\mathrm{T}$ cells attracted by the chemical 
gradient of CCR7 to present the allografts (84). Early studies usually located this process in second lymphoid organs (85), while later observation indicated that second lymphoid organs are not necessary for acute rejection: acute rejection occurs even when lacking secondary lymphoid organs $(86,87)$. The identical role of DCs in acute renal rejection could be separated into interaction with memory $\mathrm{T}$ cells and naive $\mathrm{T}$ cells, which happens in many different places including the second lymphoid organs. Taken different DCs into consideration, recipient DCs may be germane to the acute rejection as well as donor DCs (88).

\section{Chronic Rejection Based on the DC-Dependent Mechanism}

Owing to a longer lifespan, recipient DCs are more likely to mediate the chronic rejection rather than donor DCs. According to observations in mouse kidney grafts, the recipient DCs replace most of the donor DCs within $24 \mathrm{~h}$ after surgery, and over $90 \%$ DCs are derived from recipients on the 7 th day after transplantation (57). Subsequently, these DCs originated from monocytes in the host, but a few donor DCs still survive to activate T cells (57). The interaction between DCs and T cells has been more stable and prolonged since DCs reach into the renal cortex to arrest antigen-specific T cells around the endothelium with no regard to the chemical gradient. Independent of the chemical gradient, interruption of the protracted connection with $\mathrm{T}$ cells induces tolerance $(89,90)$. Also, infiltrating DCs activate $\mathrm{B}$ cells to promote chronic allograft rejection with the assist of T helper cells. This procedure depends on recipient DCs presenting antigen to recipient $\mathrm{T}$ helper cells, but the molecular mechanism remains elucidated (91-94). A few clinical trials are targeting this approach, whereas more current studies are paying attention to mediate tolerance taking advantage of the tolerogenic DCs and Tregs (95).

\section{TOLEROGENIC DCs IN RENAL TRANSPLANTATION}

\section{Remarkable Features of Tolerogenic DCs}

As a pivotal part of innate immunity, tolerogenic DCs are usually defined as immature rejection-related DCs $(96,97)$. Tolerogenic DCs, also called DCregs, circulate in the body quiescently responding to endogenous or exogenous stimuli, for example, endogenous alarmins. These tolerogenic DCs exhibit poor expression of MHC, T cell co-stimulatory molecules like CD40, CD80/86, as well as $\mathrm{T}$ cell co-inhibitory ligands (e.g., programmed death ligand-1 and death-inducing ligands), presenting non-phagocyte properties (16-20) (Table 1). Meanwhile, these DCs express a larger amount of the macrophage inhibitor cytokine than rejection-related DCs (98). Moreover, tolerogenic DCs can change the amount of C1q on its surface approaching the mature state with the assistance of globular C1q receptors $(99,100)$. C1q, a complement subunit, mediates IL-10 secretion involved in the interaction between DCs and myeloid or lymphoid cells (101-103). Besides, tolerogenic DCs confine promoting inflammatory factors including IL-12p70 into a low level while producing a high level of anti-inflammatory molecular-like transforming growth factor $\beta$ as well as IL-10 (104) (Figure 3).

According to transcription analysis, the $\mathrm{Wnt} / \beta$-catenin pathway programs tolerogenic DCs to maintain a series of unique molecular markers (105-108), and tolerogenic DCs specifically express some genes, including CNGA1, CCL18, C1QB, MUCL1, MAP7, C1QC, CYP7B1, and CYP24A1 (109). Compared to immunologic DC, tolerogenic DCs possess a steady oxidative phosphorylation program and favor fatty acid oxidation associated with decreased reactive oxygen species (110). Based on these features, tolerogenic DCs stimulate T cells weakly or even suppress the function of T cells via anergy or apoptosis for long-term immaturity (111). Additionally, tolerogenic DCs can spare, expand, and induce Tregs as shown in Figure 3 (111-113). The interaction between tolerogenic DCs and divergent $\mathrm{T}$ cells results in conditions such as allograft rejection, hematopoietic stem cell transplantation, graft-versushost diseases, and autoimmune disorders (111, 114-116). But the specific mechanism buried in these phenomena remains elusive. Therefore, an increasing number of studies incorporate tolerogenic DCs into clinical trials in organ transplantation and autoimmune diseases (117-119).

\section{Tolerogenic DCs Possible Anti-Rejection Effects}

DCs inducing tolerance was first discovered in 1995/1996 (120, 121). Tolerogenic DCs have the potential to suppress allograft rejection because DCs with $\mathrm{CD}^{-} 6^{-}$markers exist in transplant recipients compared with healthy people using single-cell RNA sequence (122). Also, infusion of tolerogenic DCs appears to be reliable and acceptable with or without immunosuppressive agents, which probably provides anti-rejection therapy in the future $(111,123)$. Ezzelarab et al. infused donor-derived tolerogenic DCs processed by vitamin D3, IL-10 into rhesus macaque models, showing that graft survival prolonged with no evidence of host sensitization (124). Autologous tolerogenic DC infusion could also lengthen the survival time of grafts, and murine IL-10-induced DCs can function as rejection inhibitors in vivo and in vitro expressing lower levels of MHCII, CD40, CD86, CD205 (125-127).

Donor-derived tolerogenic DCs can interact with alloreactive memory $\mathrm{T}$ cells including $\mathrm{CD}^{+}$and $\mathrm{CD}^{+}$cells $(128,129)$ (Figure 3). In specific, tolerogenic DCs increase allograft survival time relying on co-inhibition of cytotoxic $\mathrm{T}$ lymphocyte antigen-4 (CTLA-4) downregulation (128) (Figure 3), and coinhibitory CTLA-4 blocker treatment has the potential to improve prognosis in renal allografts $(130,131)$. Moreover, DC-induced $\mathrm{CD}^{+} 5^{+}$memory $\mathrm{T}$ cells could be an immunosuppressive phenotype with increased expression of programmed death-1 as well as coinhibitory CTLA-4 via Eomesodermin (an essential transcription factor maintenance) $(124,128,132)$. Thereafter, the infusion of coinhibitory CTLA-4 immune globulin and tolerogenic DCs promotes transplant tolerance $(129,133)$. In this promotion, high expression of 


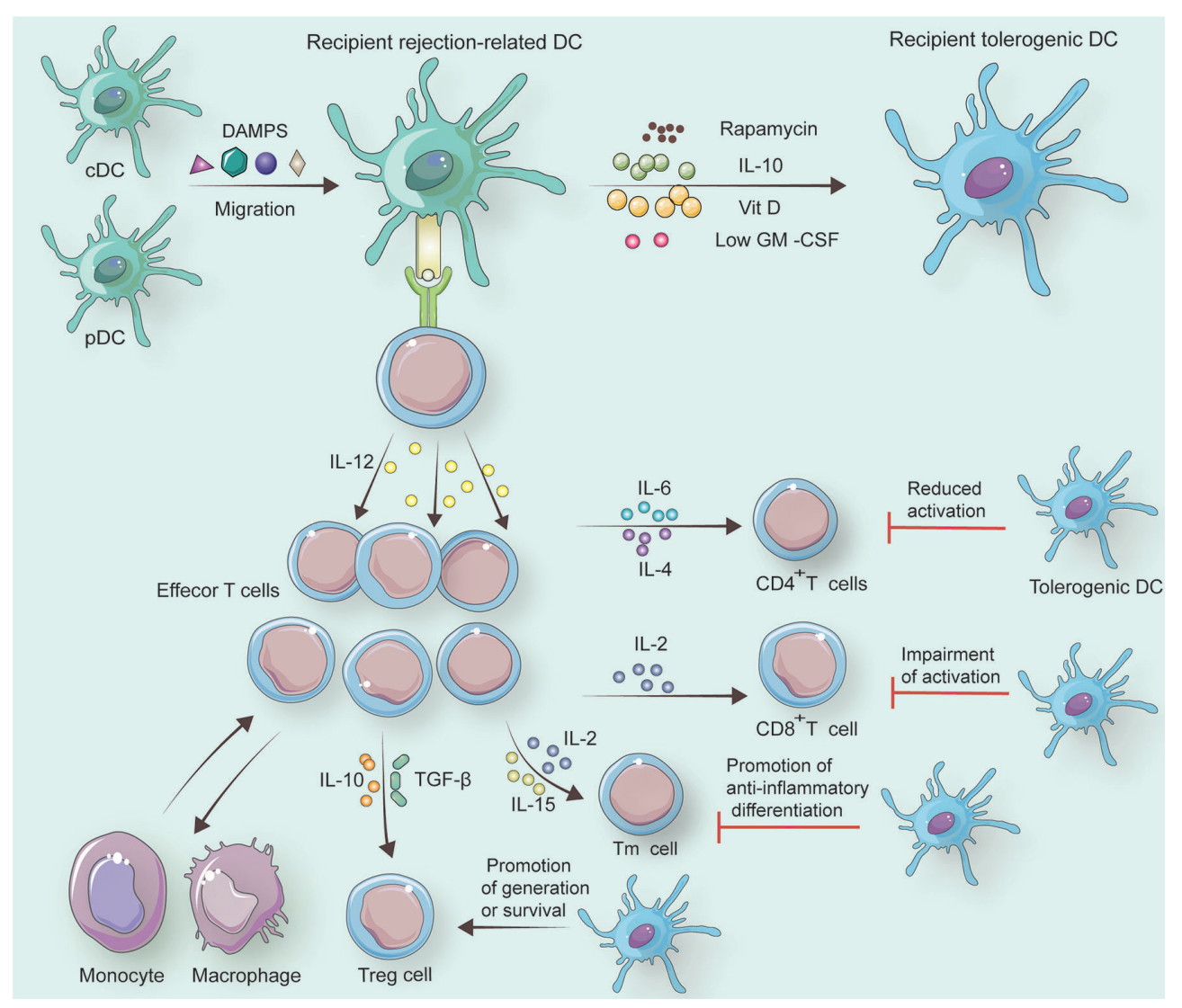

FIGURE 3 | In response to specific factors including DAMPs, recipient cDCs and pDCs change into recipient rejection-related DCs. If rapamycin, IL-10, Vit D, or a low dose of GM-CSF is employed to treat recipient rejection-related DCs, recipient tolerogenic DCs can be generated. Under the control of recipient rejection-related DCs, naive T cells differentiate to CD8 ${ }^{+} \mathrm{T}$ cells with the help of IL-2 and differentiate to CD4 ${ }^{+} \mathrm{T}$ cells assisted by IL-6 and IL-4. Memory T cells (Tm cells) also originate from naive T cells, and this alteration is associated with IL-2 and IL-15. Treg cells can occur when IL-10 and TGF- $\beta$ are secreted by recipient rejection-related DCs. Besides, tolerogenic DCs reduce $\mathrm{CD}^{+} \mathrm{T}$ cell activation, and they can impair active $\mathrm{CD} 8^{+} \mathrm{T}$ cells. Furthermore, Tm cells tend to be anti-inflammatory promoted by tolerogenic DCs. Treg cells survive for a longer period with tolerogenic DCs than with rejection-related DCs.

immune-globulin-like transcript 3 and immune-globulin-like transcript 4 causes $\mathrm{CD} 4^{+} \mathrm{CD} 45 \mathrm{RO}^{+} \mathrm{CD} 25^{+} \mathrm{T}$ cells to become Tregs mediated by the enzyme indoleamine 2, 3-dioxygenase in allografts (134) (135). As a result, the identical indoleamine-2,3dioxygenase and immunoglobulin-l like transcript 3 as well as high expressions of both MAP7 and MUCL1 genes occur in the mechanism of vitamin D3 inducted tolerogenic DCs (136-140) (Figure 3).

Donor-derived tolerogenic DCs can prolong graft survival time: treatment of these DCs ensures graft survival another 50 to 300 days (125). Donor tolerogenic DCs regulate $\mathrm{CD} 8^{+}$as well as $\mathrm{CD}^{+}$memory $\mathrm{T}$ cell responses, and this regulation prevents potential rejections (141-145). These DCs capture vesicles containing allograft antigens but choose an anti-inflammation phenotype: the number of donor-reactive IL- $17^{+} \mathrm{T}$ cells remains low $(125,146)$. Further, donor-derived tolerogenic DCs induced by vitamin D3 and IL-10 moderate IL-17 associated inflammation and maintain stability even exposed to inflammatory molecules (124, 147). Most importantly, humans produce no specific antibody against injecting tolerogenic DCs (124). Moreover, without active recipient $\mathrm{T}$ cells, harmful antibodies derived from B cells will be reduced (148). Besides, multiple subsets of freshly isolated human DCs, including non-conventional plasmacytoid DCs, can regulate immune responses as well (107, 108, 149). Table 2 summarizes the versatile roles of DCs targeting solving rejection problems in renal transplantation, implying future evaluable clinical advances (153).

\section{The Generation of Tolerogenic DCs}

Various cytokines and similar materials serve as triggers in vivo. Exposure to donor blood and immunosuppressive mediators, rapamycin, for example, might be a useful method in a nonhuman primate model $(124,129)$. Also, effective tolerogenic DCs can be endogenous. However, recipients' natural killer cells tend to kill donor-derived DCs that can mediate Tregs. Addressing this issue, Morelli and colleagues deleted host DCs to protect the donor-derived DCs from being killed (154). Through this method, recipient DCs acquired exosomes released by the donor tolerogenic DCs and amplified the effect of tolerance via the third mechanism mentioned in The Possible Downstream 
TABLE 2 | Versatile roles of DCs in renal transplantation.

\begin{tabular}{|c|c|c|c|c|}
\hline $\begin{array}{l}\text { Animal } \\
\text { Models }\end{array}$ & Interventions & Results & Functional roles or mechanisms & References \\
\hline Rat & i.v. tolerogenic DCs derived from donors & $\begin{array}{l}\text { increasing content of CD4+CD25 } \\
\text { +Foxp3+Tregs and up-regulated } \\
\text { secretion of Th2 cytokines }\end{array}$ & $\begin{array}{l}\text { The enzyme indoleamine 2, 3-dioxygenase in } \\
\text { tolerogenic DCs may induce allograft immunotolerance. }\end{array}$ & $(135)$ \\
\hline Monkey & $\begin{array}{l}\text { i.v. CTLA-4 immunoglobulin and tapered } \\
\text { rapamycin }\end{array}$ & $\begin{array}{l}\text { Graft median survival time } \\
\text { prolongation as well as } \mathrm{IL}-17 \\
\text { production attenuation combined } \\
\text { with no circulating anti-donor } \\
\text { antibody }\end{array}$ & $\begin{array}{l}\text { The beneficial effect of donor Ag-pulsed autologous } \\
\text { tolerogenic DC on nonhuman primate graft survival may } \\
\text { be modest but not statistically significant. }\end{array}$ & $(125)$ \\
\hline Monkey & i.v. donor-derived regulatory dendritic cell & $\begin{array}{l}\text { Tolerogenic DC-mediated } \\
\text { tolerance with or without } \\
\text { cytotoxic T-lymphocyte- } \\
\text { associated antigen activation. }\end{array}$ & $\begin{array}{l}\text { Pre-transplant DCreg infusion promotes tolerance after } \\
\text { transplantation with no regard to CD28 blockade. }\end{array}$ & $(129)$ \\
\hline Mouse & $\begin{array}{l}\text { Renal DCs were studied in collagenase- } \\
\text { digested mouse kidneys }\end{array}$ & $\begin{array}{l}\text { DCs migrate from the renal } \\
\text { interstitial to renal lymph node } \\
\text { within } 48 \mathrm{~h} \text { accompanied by } \\
\text { increased DCs }\end{array}$ & $\begin{array}{l}\text { Renal DCs respond to localized or systemic acute } \\
\text { kidney injury by increasing the transport of protein } \\
\text { antigens from the kidney to lymph nodes. }\end{array}$ & $(74)$ \\
\hline Mouse & Antigen coupled to an anti-CD205 antibody & $\begin{array}{l}\text { Antigen-specific CD8 T-cell } \\
\text { deletional } \\
\text { tolerance }\end{array}$ & $\begin{array}{l}\text { DEC-205 provides an effective receptor mechanism for } \\
\text { DCs to deal with MHC class I presentation in vivo, } \\
\text { which makes DCs produce stable immune tolerance } \\
\text { and immune response after maturation. }\end{array}$ & $(150)$ \\
\hline $\begin{array}{l}\text { Rhesus } \\
\text { monkey }\end{array}$ & $\begin{array}{l}\text { i.v. MD-3 anti- intercellular adhesion } \\
\text { molecule antibody combined with low dose } \\
\text { rapamycin and CD154 }\end{array}$ & $\begin{array}{l}\text { Long-term survival of pig } \\
\text { xenoislets }\end{array}$ & $\begin{array}{l}\text { The maturation of DCs relies on intercellular adhesion } \\
\text { molecule-1 and anti-intercellular adhesion molecule-1- } \\
\text { induced antigen-specific T cell tolerance. }\end{array}$ & $(151)$ \\
\hline $\begin{array}{l}\text { Humanized } \\
\text { mouse }\end{array}$ & i.v. MD-3 antibody before transplantation & $\begin{array}{l}\text { Xenospecific T-cell tolerance; } \\
\text { prevention of xenoislet rejection }\end{array}$ & $\begin{array}{l}\text { The maturation of DCs relies on intercellular adhesion } \\
\text { molecule-1 and anti-intercellular adhesion molecule-1 } \\
\text {-induced antigen-specific T cell tolerance. }\end{array}$ & $(151)$ \\
\hline $\begin{array}{l}\text { Cynomolgus } \\
\text { monkey }\end{array}$ & $\begin{array}{l}\text { i.d. immunization with antigen fused to anti- } \\
\text { DC-asialoglycoprotein receptor antibody } \\
\text { every } 5-6 \text { weeks after the flu virus }\end{array}$ & $\begin{array}{l}\text { Ag-specific, IL-10 producing } \\
\text { Tregs in vivo }\end{array}$ & $\begin{array}{l}\text { human DCs can generate antigen-specific suppressive } \\
\text { CD4 T cells that produce interleukin } 10 \text { via DC- } \\
\text { asialoglycoprotein receptor but not Dectin-1 or DC- } \\
\text { specific intercellular adhesion molecule-3-grabbing } \\
\text { nonintegrin. }\end{array}$ & $(152)$ \\
\hline $\begin{array}{l}\text { Rhesus } \\
\text { macaques }\end{array}$ & $\begin{array}{l}\text { i.v. DCreg + B7-CD28 costimulation } \\
\text { blocking agent cytotoxic T-lymphocyte- } \\
\text { associated antigen immunoglobin, } 7 \text { days } \\
\text { before renal transplantation and for up to } 8 \\
\text { weeks }\end{array}$ & $\begin{array}{l}\text { Median graft survival time was } \\
39.5 \text { days in control monkeys } \\
\text { and } 113.5 \text { days in tolerogenic } \\
\text { DCs treated animals }\end{array}$ & $\begin{array}{l}\text { Tolerogenic DCs generated from cytokine-mobilized } \\
\text { donor blood monocytes in vitamin D3 and IL-10 } \\
\text { moderate combined T cell- and antibody-mediated } \\
\text { rejection. }\end{array}$ & $(124)$ \\
\hline
\end{tabular}

Effects of DCs in Kidney Allograft Rejection (60). A few cytokines are able to induce tolerogenic DCs in vitro, for example, IL-10 and TGF- $\beta$ (optimal inducible factors) (155) (Figure 4). IL-10 decreases MHC-II expression and costimulatory molecules in DC $(156,157)$. TGF- $\beta$ increases the expression level of programmed death-ligand 1 and Fas-ligand on DC, inducing $\mathrm{T}$ cell apoptosis, and Treg differentiation $(158,159)$. Also, valuable methods can be used to produce tolerogenic DCs in vitro such as soluble Schistosoma Mansoni egg antigen, tumor necrosis factor $\alpha$-induced protein 8 like-1, human soluble CD83, and prostaglandin E2 (PGE2). Soluble Schistosoma Mansoni egg antigen increases IL-10 level and suppresses Il-12p40 secretion, implying a novel method of tolerogenic DC generation (160). Except for IL-10 and TGF- $\beta$, tumor necrosis factor $\alpha$-induced protein 8 like- 1 could control the $\mathrm{T}$ cell activation procedure $(161,162)$. Human soluble CD83 alone achieves kidney allograft tolerance ( $>100$ days) involving tolerogenic DC generation and indoleamine 2,3-dioxygenase activation (163). Mature DCs treated with PGE2 could inhibit inflammation via IL-10 secretion $(164,165)$. Traditional immunosuppressants can also serve as inducers of tolerogenic DCs, for instance, rapamycin and dexamethasone (166-170). Tolerogenic DCs generated from dexamethasone exhibit few costimulatory molecules or proinflammatory cytokines (171). Besides, metastasis-associated lung adenocarcinoma transcript 1, mesenchymal stem cells, nuclear paraspeckle assembly transcript 1, LF 15-0195, and pluripotent stem cells have a potential capacity to facilitate the tolerogenic DCs since they have been proven in other organ transplants (172-174).

Tolerogenic DC activation relies on adenosine triphosphate derived from glycolysis and tricarboxylic acid. Thus, control of glycolysis regulates DCs in renal transplantation especially in a few key active sites $(175,176)$. For instance, insufficient energy support causes morphological alteration and disorders in migration to lymph nodes (177). Lipopolysaccharide, complement component $\mathrm{C} 1 \mathrm{q}$ subcomponent-binding protein, 2-deoxyglucose, and 1,25-dihydroxy vitamin D3 are associated with oxidative phosphorylation, fatty acid oxidation, and reactive oxygen species. In glycolysis, lipopolysaccharide mediates fatty acid synthesis forming adenosine triphosphate to trigger DC activation (178). C1q subcomponent-binding protein participates in the tricarboxylic acid cycle via regulating pyruvate dehydrogenase as a chaperone protein (179). 2deoxyglucose plays an essential role in reducing CD40, CD86, 


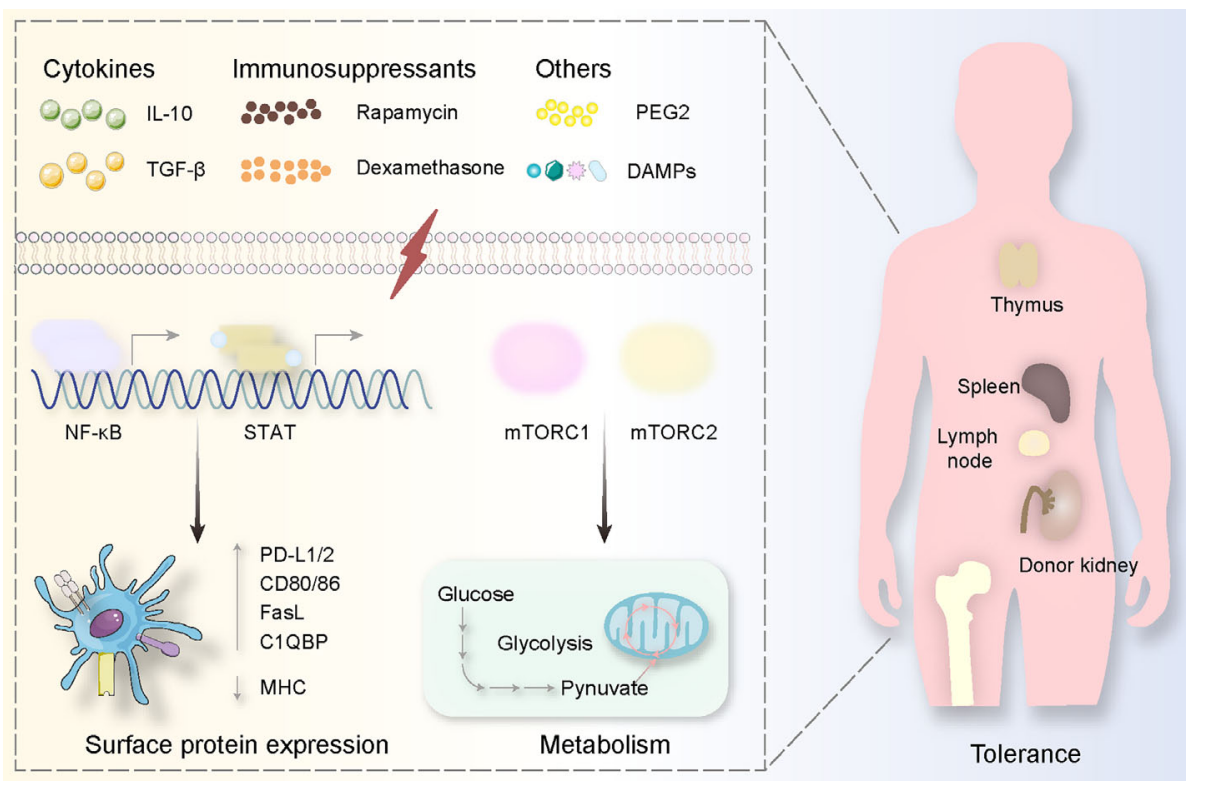

FIGURE 4 | Tolerogenic DCs are usually generated via specific substances. These stimulations derived from cytokines (IL-10, TGF- $\beta$ ), immunosuppressants (Rapamycin, Dexamethasone), and others (PEG2, DAMPs) mediate signal pathways involving NF- $\kappa$ B and mTOR activation, causing surface protein expression alterations (highly expressing PD-L1/2, CD80/86, FasL C1QBP while decreasing MHC expression) and metabolism changes (from glucose to pynuvate). All these procedures happen in the donor kidney and the immune organs including the thymus, spleen, lymph node, and bone marrow.

and MHC-II expression and secreting IL-6, IL-12p70, and TNF, which can be defined as features of tolerogenic DCs (178). Oxidative phosphorylation and fatty acid oxidation can be regulated by paracrine-derived Wnt5a protein linked tolerogenic DC generation, vitamin D3 or 1,25-dihydroxy vitamin D3 induction of tolerogenic DCs, and dexamethasone mediated tolerance $(109,180,181)$. Specifically, these materials generate tolerogenic DCs through inducible nitric oxide synthase, nuclear factor E2-related factor 2: inducible nitric oxide synthase reduces oxidative phosphorylation and fatty acid oxidation, but nuclear factor E2-related factor 2 decreases the amount of inducible nitric oxide synthase expression (182, 183). As for the relationship between oxidative phosphorylation and fatty acid oxidation, miR-142 links to carnitine palmitoyltransferase-1a and induces more active fatty acid oxidation and further increases glycolysis promoting proinflammatory cytokines (184). Fatty acid inhibits oxidative phosphorylation and facilitates reactive oxygen species leading to more severe inflammation (185-187).

In addition to general metabolism, it is accurate and stable to induce tolerogenic DCs employing regulating signal pathways. The most well-known pathway that has been focused on is mTOR (mammalian target of rapamycin) involving mTOR complex 1 (mTORC1) as well as mTOR complex 2 (mTORC2) (Figure 4). The inhibition of mTOR produces tolerogenic DCs associated with glucose metabolism. GM-CSF, IL-4, rapamycin, alum, and graphene quantum dots have effects on mTOR mediating potential tolerance via lower adenosine triphosphate generation (167, 188-190). Specifically, mTORC2 decreases adenosine triphosphate generated from mTORC1 mediating glycolysis, and mTORC1 takes crucial tasks in DC maturation (191) (Figure 4). Also, the upstream and downstream molecules contribute to the generation of tolerogenic DCs (Figure 2). An upstream complex called adenosine monophosphate-activated protein kinase can be suppressed by polyphenol resveratrol causing poor expression of mTOR (192). A downstream complex named after the peroxisome proliferatorsactivated receptor plays a metabolic role in DC maturation through targeting at mTORC1 and hypoxia-inducible factorla as a downstream complex serves to reprogram glycolysis for DC maturation via mTOR activation (177, 193-195). Reprogramming glycolysis in DCs can be finished by another kinase known as spleen tyrosine kinase depending on the production of IL-1b through a different mechanism compared with infection $(196,197)$.

STAT and NF- $\kappa \mathrm{B}$ have also been incorporated into the maturity of DC as a family containing STAT1, STAT2, STAT3, STAT4, STAT5a, STAT5b, STAT6 as well as inhibiting STAT1, STAT2, and STAT5, and activating STAT3 induces tolerogenic DCs $(198,199)$ (Figures 2, 4). Targeting at STAT1, flavonoids decrease the expression of programmed death-ligand 1 to enable DCs more mature $(200,201)$. Silencing STAT1 with small interfering RNA in DCs causes low expression of CD83 and CD86, implying antiinflammatory effects (202). STAT2 functions as a co-worker with STAT1 mediating cross-presentation of DC, and thus STAT2 should be suppressed when tolerogenic DCs are needed (203). STAT3 activation provides tolerogenic DCs because IFN- $\alpha$-induced programmed death-ligand 1 expression is inhibited by suppressed STAT3, and STAT3- 
deficient DC could increase pro-inflammatory cytokines, promote antigen-dependent $\mathrm{T}$ cell activation $(204,205)$. With STAT5 inhibited by JQ1 in lipopolysaccharide-mediated DCs, the level of IL-12p70 secretion is decreased (206). Moreover, materials preventing NF- $\kappa \mathrm{B}$ like small interfering RNA and Bay11-7082 have the potential to generate tolerogenic DCs in that they can serve as immunosuppressive tools in other organ transplants $(207,208)$ (Figure 4).

\section{CONCLUSIONS AND POSSIBLE THERAPEUTIC PROSPECTS}

Compared with macrophages in kidney transplantation, renal DCs' roles in ischemia-reperfusion, rejection or tolerance still need to clarify. For further investigation, a unified standard to separate kidney DCs from macrophages must be established based on the current level, since macrophages and DCs are both essential parts of innate immunity and they often function together inducing rejection or tolerance. This objective can be promoted by high-dimensional analysis of single-cell because increasing kidney biopsy samples provide an opportunity for revealing the markers and transcription different from macrophages. Additionally, the comparison of normal kidney and rejected kidney engenders valuable hypothesis and remarkable conclusions analyzed by artificial intelligence. In some respects, researchers tend to establish mouse models in experiments and this choice produces numerous discoveries and hinders translational medicine. Kidney transplantation saves tens of thousands of patients' lives every year and costs millions of dollars handling

\section{REFERENCES}

1. Van Furth R, Cohn ZA. The Origin and Kinetics of Mononuclear Phagocytes. J Exp Med (1968) 128(3):415-35. doi: 10.1084/jem.128.3.415

2. Nelson PJ, Rees AJ, Griffin MD, Hughes J, Kurts C, Duffield J. The Renal Mononuclear Phagocytic System. J Am Soc Nephrol (2012) 23(2):194-203. doi: 10.1681/asn.2011070680

3. Kurts C, Panzer U, Anders HJ, Rees AJ. The Immune System and Kidney Disease: Basic Concepts and Clinical Implications. Nat Rev Immunol (2013) 13(10):738-53. doi: 10.1038/nri3523

4. Steinman RM, Cohn ZA. Identification of a Novel Cell Type in Peripheral Lymphoid Organs of Mice. I. Morphology, Quantitation, Tissue Distribution. J Exp Med (1973) 137(5):1142-62. doi: 10.1084/jem.137.5.1142

5. Hume DA, Gordon S. Mononuclear Phagocyte System of the Mouse Defined by Immunohistochemical Localization of Antigen F4/80. Identification of Resident Macrophages in Renal Medullary and Cortical Interstitium and the Juxtaglomerular Complex. J Exp Med (1983) 157 (5):1704-9. doi: 10.1084/jem.157.5.1704

6. Krüger T, Benke D, Eitner F, Lang A, Wirtz M, Hamilton-Williams EE, et al. Identification and Functional Characterization of Dendritic Cells in the Healthy Murine Kidney and in Experimental Glomerulonephritis. J Am Soc Nephrol (2004) 15(3):613-21. doi: 10.1097/01.asn.0000114553.36258.91

7. Gottschalk C, Kurts C. The Debate About Dendritic Cells and Macrophages in the Kidney. Front Immunol (2015) 6:435. doi: 10.3389/fimmu.2015.00435

8. Regev A, Teichmann SA, Lander ES, Amit I, Benoist C, Birney E, et al. Science Forum: The Human Cell Atlas. Elife (2017) 6:e27041. doi: 10.7554/ eLife. 27041 rejection-associated problems meanwhile. Although donor DCs might mediate tolerance in vivo, patients still rely on traditional glucocorticoids and non-specific immunosuppress drugs. As a result, translational medicine should be emphasized immediately after the roles of DCs in renal transplantation being clarified. Finally, the relationship between rejection and tolerance and DCS is relatively clear, but the relationship between DCs and other complications of renal transplantation is still in a vague state. For example, infection related to renal transplantation may be related to intestinal flora, and the effect of intestinal flora on host immune status is likely to be achieved through DCs. In addition, the lifespan of donor DCS is not as long as that of recipient DCs, so the details of the interaction between the two DCS will also be the key to anti-rejection intervention at different time points after renal transplantation. On this basis, the understanding of the interaction between DCs and $\mathrm{T}$ cells of each transcript will also provide support for the development of anti-rejection drugs after transplantation.

\section{AUTHOR CONTRIBUTIONS}

All authors listed have made a substantial, direct, and intellectual contribution to the work and approved it for publication.

\section{FUNDING}

The research reported in this study was funded by the Natural Science Foundation of China (81770752).

9. Young MD, Mitchell TJ, Vieira Braga FA, Tran MGB, Stewart BJ, Ferdinand JR, et al. Single-Cell Transcriptomes From Human Kidneys Reveal the Cellular Identity of Renal Tumors. Science (2018) 361(6402):594-9. doi: 10.1126/science.aat1699

10. Segerer S, Heller F, Lindenmeyer MT, Schmid H, Cohen CD, Draganovici D, et al. Compartment Specific Expression of Dendritic Cell Markers in Human Glomerulonephritis. Kidney Int (2008) 74(1):37-46. doi: 10.1038/ ki.2008.99

11. Mueller FB, Yang H, Lubetzky M, Verma A, Lee JR, Dadhania DM, et al. Landscape of Innate Immune System Transcriptome and Acute T CellMediated Rejection of Human Kidney Allografts. JCI Insight (2019) 4(13): e128014. doi: 10.1172/jci.insight.128014

12. Guilliams M, Ginhoux F, Jakubzick C, Naik SH, Onai N, Schraml BU, et al. Dendritic Cells, Monocytes and Macrophages: A Unified Nomenclature Based on Ontogeny. Nat Rev Immunol (2014) 14(8):571-8. doi: 10.1038/ nri3712

13. Dong X, Swaminathan S, Bachman LA, Croatt AJ, Nath KA, Griffin MD. Resident Dendritic Cells are the Predominant TNF-secreting Cell in Early Renal Ischemia-Reperfusion Injury. Kidney Int (2007) 71(7):619-28. doi: $10.1038 /$ sj.ki.5002132

14. Dai H, Thomson AW, Rogers NM. Dendritic Cells as Sensors, Mediators, and Regulators of Ischemic Injury. Front Immunol (2019) 10:2418. doi: 10.3389/fimmu.2019.02418

15. Jongbloed SL, Kassianos AJ, McDonald KJ, Clark GJ, Ju X, Angel CE, et al. Human CD141+ (Bdca-3)+ Dendritic Cells (Dcs) Represent a Unique Myeloid DC Subset That Cross-Presents Necrotic Cell Antigens. J Exp Med (2010) 207(6):1247-60. doi: 10.1084/jem.20092140 
16. Steinman RM, Adams JC, Cohn ZA. Identification of a Novel Cell Type in Peripheral Lymphoid Organs of Mice. IV. Identification and Distribution in Mouse Spleen. J Exp Med (1975) 141(4):804-20. doi: 10.1084/jem.141.4.804

17. Marín E, Cuturi MC, Moreau A. Tolerogenic Dendritic Cells in Solid Organ Transplantation: Where Do We Stand? Front Immunol (2018) 9:274. doi: 10.3389/fimmu.2018.00274

18. Zahorchak AF, Macedo C, Hamm DE, Butterfield LH, Metes DM, Thomson AW. High PD-L1/CD86 MFI Ratio and IL-10 Secretion Characterize Human Regulatory Dendritic Cells Generated for Clinical Testing in Organ Transplantation. Cell Immunol (2018) 323:9-18. doi: 10.1016/ j.cellimm.2017.08.008

19. Lu L, Thomson AW. Manipulation of Dendritic Cells for Tolerance Induction in Transplantation and Autoimmune Disease. Transplantation (2002) 73(1 SUPPL.):S19-22. doi: 10.1097/00007890-200201151-00008

20. Lu L, Qian S, Hershberger PA, Rudert WA, Lynch DH, Thomson AW. Fas Ligand (CD95L) and B7 Expression on Dendritic Cells Provide CounterRegulatory Signals for T Cell Survival and Proliferation. J Immunol (1997) 158(12):5676-84.

21. Schlitzer A, Sivakamasundari V, Chen J, Sumatoh HR, Schreuder J, Lum J, et al. Identification of CDC1- and Cdc2-Committed DC Progenitors Reveals Early Lineage Priming at the Common DC Progenitor Stage in the Bone Marrow. Nat Immunol (2015) 16(7):718-28. doi: 10.1038/ni.3200

22. Worbs T, Hammerschmidt SI, Förster R. Dendritic Cell Migration in Health and Disease. Nat Rev Immunol (2017) 17(1):30-48. doi: 10.1038/ nri.2016.116

23. Alvarez D, Vollmann EH, von Andrian UH. Mechanisms and Consequences of Dendritic Cell Migration. Immunity (2008) 29(3):325-42. doi: 10.1016/ j.immuni.2008.08.006

24. Nakano H, Lyons-Cohen MR, Whitehead GS, Nakano K, Cook DN. Distinct Functions of CXCR4, CCR2, and CX3CR1 Direct Dendritic Cell Precursors From the Bone Marrow to the Lung. J Leukoc Biol (2017) 101(5):1143-53. doi: $10.1189 / \mathrm{jlb} .1 \mathrm{~A} 0616-285 \mathrm{R}$

25. Shi Q, Zhuang F, Liu JT, Li N, Chen YX, Su XB, et al. Single-Cell Analyses Reveal Functional Classification of Dendritic Cells and Their Potential Roles in Inflammatory Disease. FASEB J (2019) 33(3):3784-94. doi: 10.1096/ fj.201801489R

26. Scott CL, Bain CC, Wright PB, Sichien D, Kotarsky K, Persson EK, et al. CCR2(+)CD103(-) Intestinal Dendritic Cells Develop From DC-committed Precursors and Induce interleukin-17 Production by T Cells. Mucosal Immunol (2015) 8(2):327-39. doi: 10.1038/mi.2014.70

27. Matzinger P. Tolerance, Danger, and the Extended Family. Annu Rev Immunol (1994) 12:991-1045. doi: 10.1146/annurev.iy.12.040194.005015

28. Krüger B, Krick S, Dhillon N, Lerner SM, Ames S, Bromberg JS, et al. Donor Toll-Like Receptor 4 Contributes to Ischemia and Reperfusion Injury Following Human Kidney Transplantation. Proc Natl Acad Sci USA (2009) 106(9):3390-5. doi: 10.1073/pnas.0810169106

29. LaRosa DF, Rahman AH, Turka LA. The Innate Immune System in Allograft Rejection and Tolerance. J Immunol (2007) 178(12):7503-9. doi: 10.4049/ jimmunol.178.12.7503

30. Rao DA, Pober JS. Endothelial Injury, Alarmins, and Allog Raft Rejection. Crit Rev Immunol (2008) 28(3):229-48. doi: 10.1615/critrevimmunol.v28.33.40

31. Kono H, Rock KL. How Dying Cells Alert the Immune System to Danger. Nat Rev Immunol (2008) 8(4):279-89. doi: 10.1038/nri2215

32. Spörri R, Reis e Sousa C. Inflammatory Mediators are Insufficient for Full Dendritic Cell Activation and Promote Expansion of CD4+ T Cell Populations Lacking Helper Function. Nat Immunol (2005) 6(2):163-70. doi: $10.1038 /$ nil162

33. Tesar BM, Zhang J, Li Q, Goldstein DR. TH1 Immune Responses to Fully MHC Mismatched Allografts are Diminished in the Absence of MyD88, a Toll-Like Receptor Signal Adaptor Protein. Am J Transplant (2004) 4 (9):1429-39. doi: 10.1111/j.1600-6143.2004.00544.x

34. McKay D, Shigeoka A, Rubinstein M, Surh C, Sprent J. Simultaneous Deletion of MyD88 and Trif Delays Major Histocompatibility and Minor Antigen Mismatch Allograft Rejection. Eur J Immunol (2006) 36(8):19942002. doi: $10.1002 /$ eji.200636249

35. Oberbarnscheidt MH, Obhrai JS, Williams AL, Rothstein DM, Shlomchik WD, Chalasani G, et al. Type I Interferons are Not Critical for Skin Allograft Rejection or the Generation of Donor-Specific CD8+ Memory T Cells: Brief
Communication. Am J Transplant (2010) 10(1):162-7. doi: 10.1111/j.16006143.2009.02871.x

36. Li H, Matte-Martone C, Tan HS, Venkatesan S, McNiff J, Demetris AJ, et al. Graft-Versus-Host Disease is Independent of Innate Signaling Pathways Triggered by Pathogens in Host Hematopoietic Cells. J Immunol (2011) 186 (1):230-41. doi: 10.4049/jimmunol.1002965

37. Bingaman AW, Ha J, Waitze SY, Durham MM, Cho HR, Tucker-Burden C, et al. Vigorous Allograft Rejection in the Absence of Danger. J Immunol (2000) 164(6):3065-71. doi: 10.4049/jimmunol.164.6.3065

38. Anderson CC, Carroll JM, Gallucci S, Ridge JP, Cheever AW, Matzinger P. Testing Time-, Ignorance-, and Danger-Based Models of Tolerance. J Immunol (2001) 166(6):3663-71. doi: 10.4049/jimmunol.166.6.3663

39. Anderson CC, Matzinger P. Immunity or Tolerance: Opposite Outcomes of Microchimerism From Skin Grafts. Nat Med (2001) 7(1):80-7. doi: 10.1038/ 83393

40. Zecher D, Li Q, Oberbarnscheidt MH, Demetris AJ, Shlomchik WD, Rothstein DM, et al. NK Cells Delay Allograft Rejection in Lymphopenic Hosts by Downregulating the Homeostatic Proliferation of CD8+ T Cells. J Immunol (2010) 184(12):6649-57. doi: 10.4049/jimmunol.0903729

41. Larsen CP, Morris PJ, Austyn JM. Migration of Dendritic Leukocytes From Cardiac Allografts Into Host Spleens. A Novel Pathway for Initiation of Rejection. J Exp Med (1990) 171(1):307-14. doi: 10.1084/jem.171.1.307

42. MacEdo C, Orkis EA, Popescu I, Elinoff BD, Zeevi A, Shapiro R, et al. Contribution of Naïve and Memory T-Cell Populations to the Human Alloimmune Response. Am J Transplant (2009) 9(9):2057-66. doi: $10.1111 / j .1600-6143.2009 .02742 . x$

43. Suchin EJ, Langmuir PB, Palmer E, Sayegh MH, Wells AD, Turka LA. Quantifying the Frequency of Alloreactive T Cells In Vivo: New Answers to an Old Question. J Immunol (2001) 166(2):973-81. doi: 10.4049/ jimmunol.166.2.973

44. Lafferty KJ, Bootes A, Dart G, Talmage DW. Effect of Organ Culture on the Survival of Thyroid Allografts in Mice. Transplantation (1976) 22(2):13849. doi: 10.1097/00007890-197608000-00009

45. Talmage DW, Dart G, Radovich J, Lafferty KJ. Activation of Transplant Immunity: Effect of Donor Leukocytes on Thyroid Allograft Rejection. Science (1976) 191(4225):385-8. doi: 10.1126/science.1082167

46. Bowen KM, Andrus L, Lafferty KJ. Successful Allotransplantation of Mouse Pancreatic Islets to Nonimmunosuppressed Recipients. DIABETES (1980) 29(SUPPL. 1):98-104. doi: 10.2337/diab.29.1.s98

47. Batchelor JR, Welsh KI, Maynard A, Burgos H. Failure of Long Surviving, Passively Enhanced Kidney Allografts to Provoke T-dependent Alloimmunity: I. Retransplantation of (as $\times$ AUG)F1 Kidneys Into Secondary AS Recipients. J Exp Med (1979) 150(3):455-64. doi: 10.1084/ jem.150.3.455

48. Lechler RI, Batchelor JR. Restoration of Immunogenicity to Passenger CellDepleted Kidney Allografts by the Addition of Donor Strain Dendritic Cells. J Exp Med (1982) 155(1):31-41. doi: 10.1084/jem.155.1.31

49. Welsh KI, Batchelor JR, Maynard A, Burgos H. Failure of Long Surviving, Passively Enhanced Kidney Allografts to Provoke T-dependent Alloimmunity: II. Retransplantation of (as $\times$ AUG)F1 Kidneys From as Primary Recipients Into (as X WF)F1 Secondary Hosts. J Exp Med (1979) 150(3):465-70. doi: 10.1084/jem.150.3.465

50. Garrod KR, Liu FC, Forrest LE, Parker I, Kang SM, Cahalan MD. NK Cell Patrolling and Elimination of Donor-Derived Dendritic Cells Favor Indirect Alloreactivity. J Immunol (2010) 184(5):2329-36. doi: 10.4049/ jimmunol.0902748

51. Mannon RB, Griffiths R, Ruiz P, Platt JL, Coffman TM. Absence of Donor MHC Antigen Expression Ameliorates Chronic Kidney Allograft Rejection. Kidney Int (2002) 62(1):290-300. doi: 10.1046/j.1523-1755. 2002.00422.x

52. Grusby MJ, Auchincloss J, Lee R, Johnson RS, Spencer JP, Zijlstra M, et al. Mice Lacking Major Histocompatibility Complex Class I and Class II Molecules. Proc Natl Acad Sci U.S.A. (1993) 90(9):3913-7. doi: 10.1073/ pnas. 90.9 .3913

53. Garrod KR, Wei SH, Parker I, Cahalan MD. Natural Killer Cells Actively Patrol Peripheral Lymph Nodes Forming Stable Conjugates to Eliminate MHC-mismatched Targets. Proc Natl Acad Sci USA (2007) 104(29):120816. doi: $10.1073 /$ pnas. 0702867104 
54. Morelli AE. Dendritic Cells of Myeloid Lineage: The Masterminds Behind Acute Allograft Rejection. Curr Opin Organ Transplant (2014) 19(1):20-7. doi: 10.1097/MOT.0000000000000039

55. Herrera OB, Golshayan D, Tibbott R, Ochoa FS, James MJ, Marelli-Berg FM, et al. A Novel Pathway of Alloantigen Presentation by Dendritic Cells. J Immunol (2004) 173(8):4828-37. doi: 10.4049/jimmunol.173.8.4828

56. Sivaganesh S, Harper SJ, Conlon TM, Callaghan CJ, Saeb-Parsy K, Negus MC, et al. Copresentation of Intact and Processed MHC Alloantigen by Recipient Dendritic Cells Enables Delivery of Linked Help to Alloreactive CD8 T Cells by Indirect-Pathway CD4 T Cells. J Immunol (2013) 190 (11):5829-38. doi: 10.4049/jimmunol.1300458

57. Zhuang Q, Lakkis FG. Dendritic Cells and Innate Immunity in Kidney Transplantation. Kidney Int (2015) 87(4):712-8. doi: 10.1038/ki.2014.430

58. Liu Q, Rojas-Canales DM, Divito SJ, Shufesky WJ, Stolz DB, Erdos G, et al. Donor Dendritic Cell-Derived Exosomes Promote Allograft-Targeting Immune Response. J Clin Invest (2016) 126(8):2805-20. doi: 10.1172/ JCI84577

59. Marino J, Babiker-Mohamed MH, Crosby-Bertorini P, Paster JT, LeGuern C, Germana S, et al. Donor Exosomes Rather Than Passenger Leukocytes Initiate Alloreactive T Cell Responses After Transplantation. Sci Immunol (2016) 1(1):aaf8759. doi: 10.1126/sciimmunol.aaf8759

60. Lindenbergh MFS, Stoorvogel W. Antigen Presentation by Extracellular Vesicles From Professional Antigen-Presenting Cells. Annu Rev Immunol: Annu Rev Inc (2018) 36:435-59. doi: 10.1146/annurev-immunol-041015055700

61. Zhuang Q, Liu Q, Divito SJ, Zeng Q, Yatim KM, Hughes AD, et al. GraftInfiltrating Host Dendritic Cells Play a Key Role in Organ Transplant Rejection. Nat Commun (2016) 7(1):1-12. doi: 10.1038/ncomms12623

62. Joffre OP, Segura E, Savina A, Amigorena S. Cross-Presentation by Dendritic Cells. Nat Rev Immunol (2012) 12(8):557-69. doi: 10.1038/nri3254

63. Yamazaki S, Dudziak D, Heidkamp GF, Fiorese C, Bonito AJ, Inaba K, et al. Cd8+ CD205+ Splenic Dendritic Cells are Specialized to Induce Foxp3+ Regulatory T Cells. J Immunol (2008) 181(10):6923-33. doi: 10.4049/ jimmunol.181.10.6923

64. Gotot J, Dhana E, Yagita H, Kaiser R, Ludwig-Portugall I, Kurts C. AntigenSpecific Helios(-), Neuropilin-1(-) Tregs Induce Apoptosis of Autoreactive B Cells Via PD-L1. Immunol Cell Biol (2018) 96(8):852-62. doi: 10.1111/ imcb. 12053

65. den Haan JM, Lehar SM, Bevan MJ. CD8(+) But Not CD8(-) Dendritic Cells Cross-Prime Cytotoxic T Cells In Vivo. J Exp Med (2000) 192(12):1685-96. doi: $10.1084 / \mathrm{jem} .192 .12 .1685$

66. Belz GT, Behrens GM, Smith CM, Miller JF, Jones C, Lejon K, et al. The CD8alpha(+) Dendritic Cell is Responsible for Inducing Peripheral SelfTolerance to Tissue-Associated Antigens. J Exp Med (2002) 196(8):1099104. doi: $10.1084 / \mathrm{jem} .20020861$

67. Hildner K, Edelson BT, Purtha WE, Diamond M, Matsushita H, Kohyama M, et al. Batf3 Deficiency Reveals a Critical Role for CD8alpha+ Dendritic Cells in Cytotoxic T Cell Immunity. Science (2008) 322(5904):1097-100. doi: 10.1126/science.1164206

68. Kurts C, Robinson BW, Knolle PA. Cross-Priming in Health and Disease. Nat Rev Immunol (2010) 10(6):403-14. doi: 10.1038/nri2780

69. Schlichting CL, Schareck WD, Weis M. Renal Ischemia-Reperfusion Injury: New Implications of Dendritic Cell-Endothelial Cell Interactions. Transplant Proc (2006) 38(3):670-3. doi: 10.1016/j.transproceed.2006.01.059

70. Jantsch J, Chakravortty D, Turza N, Prechtel AT, Buchholz B, Gerlach RG, et al. Hypoxia and Hypoxia-Inducible Factor-1 Alpha Modulate Lipopolysaccharide-Induced Dendritic Cell Activation and Function. J Immunol (2008) 180(7):4697-705. doi: 10.4049/jimmunol.180.7.4697

71. Xu L, Sharkey D, Cantley LG. Tubular GM-CSF Promotes Late Mcp-1/Ccr2Mediated Fibrosis and Inflammation After Ischemia/Reperfusion Injury. J Am Soc Nephrol (2019) 30(10):1825-40. doi: 10.1681/asn.2019010068

72. Ferhat M, Robin A, Giraud S, Sena S, Goujon JM, Touchard G, et al. Endogenous IL-33 Contributes to Kidney Ischemia-Reperfusion Injury as an Alarmin. J Am Soc Nephrol (2018) 29(4):1272-88. doi: 10.1681/ asn. 2017060650

73. Rogers NM, Matthews TJ, Kausman JY, Kitching AR, Coates PT. Review Article: Kidney Dendritic Cells: Their Role in Homeostasis, Inflammation and Transplantation. Nephrol (Carlton) (2009) 14(7):625-35. doi: 10.1111/ j.1440-1797.2009.01200.x

74. Dong X, Swaminathan S, Bachman LA, Croatt AJ, Nath KA, Griffin MD. Antigen Presentation by Dendritic Cells in Renal Lymph Nodes is Linked to Systemic and Local Injury to the Kidney. Kidney Int (2005) 68(3):1096-108. doi: 10.1111/j.1523-1755.2005.00502.x

75. Burne-Taney MJ, Kofler J, Yokota N, Weisfeldt M, Traystman RJ, Rabb H. Acute Renal Failure After Whole Body Ischemia is Characterized by Inflammation and T Cell-Mediated Injury. Am J Physiol Renal Physiol (2003) 285(1):F87-94. doi: 10.1152/ajprenal.00026.2003

76. Ysebaert DK, De Greef KE, De Beuf A, Van Rompay AR, Vercauteren S, Persy VP, et al. T Cells as Mediators in Renal Ischemia/Reperfusion Injury. Kidney Int (2004) 66(2):491-6. doi: 10.1111/j.1523-1755.2004.761_4.x

77. Lech M, Avila-Ferrufino A, Allam R, Segerer S, Khandoga A, Krombach F, et al. Resident Dendritic Cells Prevent Postischemic Acute Renal Failure by Help of Single Ig IL-1 Receptor-Related Protein. J Immunol (2009) 183 (6):4109-18. doi: 10.4049/jimmunol.0900118

78. Kim H, Seed B. The Transcription Factor MafB Antagonizes Antiviral Responses by Blocking Recruitment of Coactivators to the Transcription Factor IRF3. Nat Immunol (2010) 11(8):743-50. doi: 10.1038/ni.1897

79. Cho WY, Choi HM, Lee SY, Kim MG, Kim HK, Jo SK. The Role of Tregs and CD11c(+) Macrophages/Dendritic Cells in Ischemic Preconditioning of the Kidney. Kidney Int (2010) 78(10):981-92. doi: 10.1038/ki.2010.266

80. Pontrelli P, Cariello M, Rascio F, Gigante M, Verrienti R, Tataranni T, et al. Thrombin may Modulate Dendritic Cell Activation in Kidney Transplant Recipients With Delayed Graft Function. Nephrol Dial Transplant (2015) 30 (9):1480-7. doi: 10.1093/ndt/gfv129

81. Stallone G, Pontrelli P, Rascio F, Castellano G, Gesualdo L, Grandaliano G. Coagulation and Fibrinolysis in Kidney Graft Rejection. Front Immunol (2020) 11:1807. doi: 10.3389/fimmu.2020.01807

82. Siu JHY, Surendrakumar V, Richards JA, Pettigrew GJ. T Cell Allorecognition Pathways in Solid Organ Transplantation. Front Immunol (2018) 9:2548. doi: 10.3389/fimmu.2018.02548

83. Merad M, Collin M, Bromberg J. Dendritic Cell Homeostasis and Trafficking in Transplantation. Trends Immunol (2007) 28(8):353-9. doi: 10.1016/ j.it.2007.06.003

84. Sallusto F, Lenig D, Förster R, Lipp M, Lanzavecchia A. Two Subsets of Memory T Lymphocytes With Distinct Homing Potentials and Effector Functions. Nature (1999) 401(6754):708-12. doi: 10.1038/44385

85. Lakkis FG, Arakelov A, Konieczny BT, Inoue Y. Immunologic 'Ignorance' of Vascularized Organ Transplants in the Absence of Secondary Lymphoid Tissue. Nat Med (2000) 6(6):686-8. doi: 10.1038/76267

86. Chalasani G, Dai Z, Konieczny BT, Baddoura FK, Lakkis FG. Recall and Propagation of Allospecific Memory T Cells Independent of Secondary Lymphoid Organs. Proc Natl Acad Sci USA (2002) 99(9):6175-80. doi: 10.1073/pnas.092596999

87. Obhrai JS, Oberbarnscheidt MH, Hand TW, Diggs L, Chalasani G, Lakkis FG. Effector T Cell Differentiation and Memory T Cell Maintenance Outside Secondary Lymphoid Organs. J Immunol (2006) 176(7):4051-8. doi: 10.4049/jimmunol.176.7.4051

88. Heeger PS, Greenspan NS, Kuhlenschmidt S, Dejelo C, Hricik DE, Schulak $J A$, et al. Pretransplant Frequency of Donor-Specific, IFN- $\gamma$-Producing Lymphocytes is a Manifestation of Immunologic Memory and Correlates With the Risk of Posttransplant Rejection Episodes. J Immunol (1999) 163 (4):2267-75.

89. Wakim LM, Waithman J, Van Rooijen N, Heath WR, Carbone FR. Dendritic Cell-Induced Memory T Cell Activation in Nonlymphoid Tissues. Science (2008) 319(5860):198-202. doi: 10.1126/science.1151869

90. Walch JM, Zeng Q, Li Q, Oberbarnscheidt MH, Hoffman RA, Williams AL, et al. Cognate Antigen Directs CD8+ T Cell Migration to Vascularized Transplants. J Clin Invest (2013) 123(6):2663-71. doi: 10.1172/JCI66722

91. Dong VM, Womer KL, Sayegh MH. Transplantation Tolerance: The Concept and its Applicability. Pediatr Transplant (1999) 3(3):181-92. doi: 10.1034/j.1399-3046.1999.00042.x

92. Zhuang Q, Liu Q, Divito SJ, Zeng Q, Yatim KM, Hughes AD, et al. GraftInfiltrating Host Dendritic Cells Play a Key Role in Organ Transplant Rejection. Nat Commun (2016) 7:12623. doi: 10.1038/ncomms12623 
93. Snelgrove SL, Lo C, Hall P, Lo CY, Alikhan MA, Coates PT, et al. Activated Renal Dendritic Cells Cross Present Intrarenal Antigens After IschemiaReperfusion Injury. Transplantation (2017) 101(5):1013-24. doi: 10.1097/ tp.0000000000001427

94. Ruben JM, García-Romo GS, Breman E, van der Kooij S, Redeker A, Arens R, et al. Human Plasmacytoid Dendritic Cells Acquire Phagocytic Capacity by TLR9 Ligation in the Presence of Soluble Factors Produced by Renal Epithelial Cells. Kidney Int (2018) 93(2):355-64. doi: 10.1016/j.kint. 2017.08.006

95. Ochando J, Ordikhani F, Jordan S, Boros P, Thomson AW. Tolerogenic Dendritic Cells in Organ Transplantation. Transpl Int (2020) 33(2):113-27. doi: $10.1111 /$ tri. 13504

96. Banchereau J, Steinman RM. Dendritic Cells and the Control of Immunity. Nature (1998) 392(6673):245-52. doi: 10.1038/32588

97. Steinman RM. Decisions About Dendritic Cells: Past, Present, and Future. Annu Rev Immunol (2012) 30:1-22. doi: 10.1146/annurev-immunol100311-102839

98. Zhou Z, Li W, Song Y, Wang L, Zhang K, Yang J, et al. Growth Differentiation factor-15 Suppresses Maturation and Function of Dendritic Cells and Inhibits Tumor-Specific Immune Response. PloS One (2013) 8(11):e78618. doi: 10.1371/journal.pone.0078618

99. Castellano G, Woltman AM, Nauta AJ, Roos A, Trouw LA, Seelen MA, et al. Maturation of Dendritic Cells Abrogates C1q Production In Vivo and In Vitro. Blood (2004) 103(10):3813-20. doi: 10.1182/blood-2003-09-3046

100. Son M, Santiago-Schwarz F, Al-Abed Y, Diamond B. C1q Limits Dendritic Cell Differentiation and Activation by Engaging LAIR-1. Proc Natl Acad Sci U.S.A. (2012) 109(46):E3160-7. doi: 10.1073/pnas.1212753109

101. Mascarell L, Airouche S, Berjont N, Gary C, Gueguen C, Fourcade G, et al. The Regulatory Dendritic Cell Marker C1q is a Potent Inhibitor of Allergic Inflammation. Mucosal Immunol (2017) 10(3):695-704. doi: 10.1038/ mi.2016.87

102. Hosszu KK, Valentino A, Vinayagasundaram U, Vinayagasundaram R, Joyce MG, Ji Y, et al. Dc-Sign, C1q, and gC1qR Form a Trimolecular Receptor Complex on the Surface of Monocyte-Derived Immature Dendritic Cells. Blood (2012) 120(6):1228-36. doi: 10.1182/blood-2011-07-369728

103. Zimmer A, Bouley J, Le Mignon M, Pliquet E, Horiot S, Turfkruyer M, et al. A Regulatory Dendritic Cell Signature Correlates With the Clinical Efficacy of Allergen-Specific Sublingual Immunotherapy. J Allergy Clin Immunol (2012) 129(4):1020-30. doi: 10.1016/j.jaci.2012.02.014

104. Maldonado RA, von Andrian UH. How Tolerogenic Dendritic Cells Induce Regulatory T Cells. Adv Immunol (2010) 108:111-65. doi: 10.1016/b978-012-380995-7.00004-5

105. Vander Lugt B, Riddell J, Khan AA, Hackney JA, Lesch J, DeVoss J, et al. Transcriptional Determinants of Tolerogenic and Immunogenic States During Dendritic Cell Maturation. J Cell Biol (2017) 216(3):779-92. doi: $10.1083 /$ jcb.201512012

106. Swafford D, Manicassamy S. Wnt Signaling in Dendritic Cells: Its Role in Regulation of Immunity and Tolerance. Discovery Med (2015) 19 (105):303-10

107. Liu YJ. Dendritic Cell Subsets and Lineages, and Their Functions in Innate and Adaptive Immunity. Cell (2001) 106(3):259-62. doi: 10.1016/S00928674(01)00456-1

108. Ueno H, Klechevsky E, Morita R, Aspord C, Cao T, Matsui T, et al. Dendritic Cell Subsets in Health and Disease. Immunol Rev (2007) 219(1):118-42. doi: 10.1111/j.1600-065X.2007.00551.x

109. Navarro-Barriuso J, Mansilla MJ, Naranjo-Gómez M, Sánchez-Pla A, Quirant-Sánchez B, Teniente-Serra A, et al. Comparative Transcriptomic Profile of Tolerogenic Dendritic Cells Differentiated With Vitamin D3, Dexamethasone and Rapamycin. Sci Rep (2018) 8(1):14985. doi: 10.1038/ s41598-018-33248-7

110. Sim WJ, Ahl PJ, Connolly JE. Metabolism Is Central to Tolerogenic Dendritic Cell Function. Mediators Inflammation (2016) 2016:2636701. doi: $10.1155 / 2016 / 2636701$

111. Morelli AE, Thomson AW. Tolerogenic Dendritic Cells and the Quest for Transplant Tolerance. Nat Rev Immunol (2007) 7(8):610-21. doi: 10.1038/ nri2 132

112. Huang H, Dawicki W, Zhang X, Town J, Gordon JR. Tolerogenic Dendritic Cells Induce CD4+CD25 hiFoxp3+ Regulatory T Cell Differentiation From
CD4 +Cd25-/loFoxp3- Effector T Cells. J Immunol (2010) 185(9):5003-10. doi: 10.4049/jimmunol.0903446

113. Raker VK, Domogalla MP, Steinbrink K. Tolerogenic Dendritic Cells for Regulatory T Cell Induction in Man. Front Immunol (2015) 6:569. doi: 10.3389/fimmu.2015.00569

114. Stenger EO, Turnquist HR, Mapara MY, Thomson AW. Dendritic Cells and Regulation of Graft-Versus-Host Disease and Graft-Versus-Leukemia Activity. Blood (2012) 119(22):5088-103. doi: 10.1182/blood-2011-11364091

115. Hilkens CMU, Isaacs JD, Thomson AW. Development of Dendritic CellBased Immunotherapy for Autoimmunity. Int Rev Immunol (2010) 29 (2):156-83. doi: 10.3109/08830180903281193

116. Thomson AW, Robbins PD. Tolerogenic Dendritic Cells for Autoimmune Disease and Transplantation. Ann Rheum Dis (2008) 67(SUPPL. 3):iii90-iii6. doi: 10.1136/ard.2008.099176

117. Verhasselt V, Vosters O, Beuneu C, Nicaise C, Stordeur P, Goldman M. Induction of FOXP3-expressing Regulatory CD4pos T Cells by Human Mature Autologous Dendritic Cells. Eur J Immunol (2004) 34(3):762-72. doi: 10.1002/eji.200324552

118. Jonuleit H, Schmitt E, Schuler G, Knop J, Enk AH. Induction of Interleukin 10-Producing, Nonproliferating CD4(+) T Cells With Regulatory Properties by Repetitive Stimulation With Allogeneic Immature Human Dendritic Cells. J Exp Med (2000) 192(9):1213-22. doi: 10.1084/jem.192.9.1213

119. Dhodapkar MV, Steinman RM, Krasovsky J, Munz C, Bhardwaj N. AntigenSpecific Inhibition of Effector T Cell Function in Humans After Injection of Immature Dendritic Cells. J Exp Med (2001) 193(2):233-8. doi: 10.1084/ jem.193.2.233

120. Rastellini C, Lu L, Ricorbi C, Starzl TE, Rao AS, Thomson AW. Granulocyte/ Macrophage Colony-Stimulating Factor-Stimulated Hepatic Dendritic Cell Progenitors Prolong Pancreatic Islet Allograft Survival. Transplantation (1995) 60(11):1366-70.

121. Fu F, Li Y, Qian S, Lu L, Chambers F, Starzl TE, et al. Costimulatory Molecule-Deficient Dendritic Cell Progenitors (MHC Class II+, CD80(Dim), CD86-) Prolong Cardiac Allograft Survival in Nonimmunosuppressed Recipients. Transplantation (1996) 62(5):659-65. doi: 10.1097/00007890199609150-00021

122. Wu H, Malone AF, Donnelly EL, Kirita Y, Uchimura K, Ramakrishnan SM, et al. Single-Cell Transcriptomics of a Human Kidney Allograft Biopsy Specimen Defines a Diverse Inflammatory Response. J Am Soc Nephrol (2018) 29(8):2069-80. doi: 10.1681/asn.2018020125

123. Beriou G, Moreau A, Cuturi MC. Tolerogenic Dendritic Cells: Applications for Solid Organ Transplantation. Curr Opin Organ Transplant (2012) 17 (1):42-7. doi: 10.1097/MOT.0b013e32834ee662

124. Ezzelarab MB, Zahorchak AF, Lu L, Morelli AE, Chalasani G, Demetris AJ, et al. Regulatory Dendritic Cell Infusion Prolongs Kidney Allograft Survival in Nonhuman Primates. Am J Transplant (2013) 13(8):1989-2005. doi: 10.1111/ajt.12310

125. Ezzelarab MB, Raich-Regue D, Lu L, Zahorchak AF, Perez-Gutierrez A, Humar A, et al. Renal Allograft Survival in Nonhuman Primates Infused With Donor Antigen-Pulsed Autologous Regulatory Dendritic Cells. Am J Transplant (2017) 17(6):1476-89. doi: 10.1111/ajt.14182

126. Madelon N, Montanari E, Gruaz L, Pimenta J, Muller YD, Bühler LH, et al. Prolongation of Rat-to-Mouse Islets Xenograft Survival by CoTransplantation of Autologous IL-10 Differentiated Murine Tolerogenic Dendritic Cells. Xenotransplantation (2020) 27(4):e12584. doi: 10.1111/ xen. 12584

127. Marinelarena A, Bhattacharya P, Kumar P, Maker AV, Prabhakar BS. Identification of a Novel Ox401(+) Dendritic Cell Subset That Selectively Expands Regulatory T Cells. Sci Rep (2018) 8(1):14940. doi: 10.1038/s41598018-33307-z

128. Ezzelarab MB, Lu L, Guo H, Zahorchak AF, Shufesky WF, Cooper DKC, et al. Eomesoderminlo CTLA4hi Alloreactive CD8+ Memory T Cells Are Associated With Prolonged Renal Transplant Survival Induced by Regulatory Dendritic Cell Infusion in CTLA4 Immunoglobulin-Treated Nonhuman Primates. Transplantation (2016) 100(1):91-102. doi: 10.1097/ TP.0000000000000871

129. Ezzelarab MB, Lu L, Shufesky WF, Morelli AE, Thomson AW. DonorDerived Regulatory Dendritic Cell Infusion Maintains Donor-Reactive CD4 
(+)CTLA4(Hi) T Cells in Non-Human Primate Renal Allograft Recipients Treated With CD28 Co-Stimulation Blockade. Front Immunol (2018) 9:250. doi: $10.3389 /$ fimmu. 2018.00250

130. Lin H, Rathmell JC, Gray GS, Thompson CB, Leiden JM, Alegre ML. Cytotoxic T Lymphocyte Antigen 4 (CTLA4) Blockade Accelerates the Acute Rejection of Cardiac Allografts in CD28-deficient Mice: CTLA4 can Function Independently of CD28. J Exp Med (1998) 188(1):199-204. doi: 10.1084/jem.188.1.199

131. Grimbert P, Audard V, Diet C, Matignon M, Plonquet A, Mansour H, et al. T-Cell Phenotype in Protocol Renal Biopsy From Transplant Recipients Treated With Belatacept-Mediated Co-Stimulatory Blockade. Nephrol Dial Transplant (2011) 26(3):1087-93. doi: 10.1093/ndt/gfq453

132. Intlekofer AM, Takemoto N, Wherry EJ, Longworth SA, Northrup JT, Palanivel VR, et al. Effector and Memory CD8+ T Cell Fate Coupled by Tbet and Eomesodermin. Nat Immunol (2005) 6(12):1236-44. doi: 10.1038/ ni1268

133. Vincenti F, Charpentier B, Vanrenterghem Y, Rostaing L, Bresnahan B, Darji P, et al. A Phase III Study of Belatacept-Based Immunosuppression Regimens Versus Cyclosporine in Renal Transplant Recipients (BENEFIT Study). Am J Transplant (2010) 10(3):535-46. doi: 10.1111/j.16006143.2009.03005.x

134. Stallone G, Pontrelli P, Infante B, Gigante M, Netti GS, Ranieri E, et al. Rapamycin Induces ILT3(high)ILT4(high) Dendritic Cells Promoting a New Immunoregulatory Pathway. Kidney Int (2014) 85(4):888-97. doi: 10.1038/ ki.2013.337

135. Na N, Luo Y, Zhao DQ, Yang SC, Hong LQ, Li H, et al. Prolongation of Kidney Allograft Survival Regulated by Indoleamine 2,3-Dioxygenase in Immature Dendritic Cells Generated From Recipient Type Bone Marrow Progenitors. Mol Immunol (2016) 79:22-31. doi: 10.1016/j.molimm. 2016.09.005

136. Széles L, Keresztes G, Töröcsik D, Balajthy Z, Krenács L, Póliska S, et al. 1,25Dihydroxyvitamin D3 is an Autonomous Regulator of the Transcriptional Changes Leading to a Tolerogenic Dendritic Cell Phenotype. J Immunol (2009) 182(4):2074-83. doi: 10.4049/jimmunol.0803345

137. Vanherwegen AS, Cook DP, Ferreira GB, Gysemans C, Mathieu C. Vitamin D-modulated Dendritic Cells Delay Lethal Graft-Versus-Host Disease Through Induction of Regulatory T Cells. J Steroid Biochem Mol Biol (2019) 188:103-10. doi: 10.1016/j.jsbmb.2018.12.013

138. Penna G, Roncari A, Amuchastegui S, Daniel KC, Berti E, Colonna M, et al. Expression of the Inhibitory Receptor ILT3 on Dendritic Cells is Dispensable for Induction of CD4+Foxp3+ Regulatory T Cells by 1,25Dihydroxyvitamin D3. Blood (2005) 106(10):3490-7. doi: 10.1182/ blood-2005-05-2044

139. Farias AS, Spagnol GS, Bordeaux-Rego P, Oliveira CO, Fontana AG, de Paula RF, et al. Vitamin D3 Induces IDO+ Tolerogenic DCs and Enhances Treg, Reducing the Severity of EAE. CNS Neurosci Ther (2013) 19(4):269-77. doi: $10.1111 /$ cns. 12071

140. Navarro-Barriuso J, Mansilla MJ, Quirant-Sánchez B, Ardiaca-Martínez A, Teniente-Serra A, Presas-Rodríguez S, et al. MAP7 and MUCL1 are Biomarkers of Vitamin D3-Induced Tolerogenic Dendritic Cells in Multiple Sclerosis Patients. Front Immunol (2019) 10:1251. doi: 10.3389/ fimmu.2019.01251

141. Divito SJ, Wang Z, Shufesky WJ, Liu Q, Tkacheva OA, Montecalvo A, et al. Endogenous Dendritic Cells Mediate the Effects of Intravenously Injected Therapeutic Immunosuppressive Dendritic Cells in Transplantation. Blood (2010) 116(15):2694-705. doi: 10.1182/blood-2009-10-251058

142. Kenna TJ, Thomas R, Steptoe RJ. Steady-State Dendritic Cells Expressing Cognate Antigen Terminate Memory CD8+ T-Cell Responses. Blood (2008) 111(4):2091-100. doi: 10.1182/blood-2007-07-103200

143. Kenna TJ, Waldie T, McNally A, Thomson M, Yagita H, Thomas R, et al. Targeting Antigen to Diverse APCs Inactivates Memory CD8+ T Cells Without Eliciting Tissue-Destructive Effector Function. J Immunol (2010) 184(2):598-606. doi: 10.4049/jimmunol.0900032

144. Nasreen M, Waldie TM, Dixon CM, Steptoe RJ. Steady-State AntigenExpressing Dendritic Cells Terminate CD4+ Memory T-cell Responses. Eur J Immunol (2010) 40(7):2016-25. doi: 10.1002/eji.200940085

145. Kleijwegt FS, Jansen DTSL, Teeler J, Joosten AM, Laban S, Nikolic T, et al. Tolerogenic Dendritic Cells Impede Priming of Naïve CD8+ T Cells and
Deplete Memory CD8+ T Cells. Eur J Immunol (2013) 43(1):85-92. doi: $10.1002 /$ eji.201242879

146. Kwan T, Chadban SJ, Ma J, Bao S, Alexander SI, Wu H. Il-17 Deficiency Attenuates Allograft Injury and Prolongs Survival in a Murine Model of Fully MHC-mismatched Renal Allograft Transplantation. Am J Transplant (2015) 15(6):1555-67. doi: 10.1111/ajt.13140

147. Zahorchak AF, Kean LS, Tokita D, Turnquist HR, Abe M, Finke J, et al. Infusion of Stably Immature Monocyte-Derived Dendritic Cells Plus CTLA4Ig Modulates Alloimmune Reactivity in Rhesus Macaques. Transplantation (2007) 84(2):196206. doi: $10.1097 / 01 . t p .0000268582 .21168 . f 6$

148. Morelli AE, Thomson AW. Orchestration of Transplantation Tolerance by Regulatory Dendritic Cell Therapy or in-Situ Targeting of Dendritic Cells. Curr Opin Organ Transplant (2014) 19(4):348-56. doi: 10.1097/ MOT.0000000000000097

149. Rogers NM, Isenberg JS, Thomson AW. Plasmacytoid Dendritic Cells: No Longer an Enigma and Now Key to Transplant Tolerance? Am J Transplant (2013) 13(5):1125-33. doi: 10.1111/ajt.12229

150. Bonifaz L, Bonnyay D, Mahnke K, Rivera M, Nussenzweig MC, Steinman RM. Efficient Targeting of Protein Antigen to the Dendritic Cell Receptor DEC-205 in the Steady State Leads to Antigen Presentation on Major Histocompatibility Complex Class I Products and Peripheral CD8+ T Cell Tolerance. J Exp Med (2002) 196(12):1627-38. doi: 10.1084/jem.20021598

151. Jung KC, Park CG, Jeon YK, Park HJ, Ban YL, Min HS, et al. In Situ Induction of Dendritic Cell-Based T Cell Tolerance in Humanized Mice and Nonhuman Primates. J Exp Med (2011) 208(12):2477-88. doi: 10.1084/ jem.20111242

152. Li D, Romain G, Flamar AL, Duluc D, Dullaers M, Li XH, et al. Targeting Self- and Foreign Antigens to Dendritic Cells Via DC-ASGPR Generates IL10-producing Suppressive CD4+ T Cells. J Exp Med (2012) 209(1):109-21. doi: 10.1084 /jem.20110399

153. Phillips BE, Garciafigueroa Y, Trucco M, Giannoukakis N. Clinical Tolerogenic Dendritic Cells: Exploring Therapeutic Impact on Human Autoimmune Disease. Front Immunol (2017) 8:1279. doi: 10.3389/ fimmu.2017.01279

154. Wang Z, Divito SJ, Shufesky WJ, Sumpter T, Wang H, Tkacheva OA, et al. Dendritic Cell Therapies in Transplantation Revisited: Deletion of Recipient DCs Deters the Effect of Therapeutic Dcs. Am J Transplant (2012) 12 (6):1398-408. doi: 10.1111/j.1600-6143.2012.04060.x

155. Boks MA, Kager-Groenland JR, Haasjes MS, Zwaginga JJ, van Ham SM, ten Brinke A. Il-10-generated Tolerogenic Dendritic Cells are Optimal for Functional Regulatory T Cell Induction-a Comparative Study of Human Clinical-Applicable DC. Clin Immunol (2012) 142(3):332-42. doi: 10.1016/ j.clim.2011.11.011

156. Comi M, Amodio G, Gregori S. Interleukin-10-Producing DC-10 is a Unique Tool to Promote Tolerance Via Antigen-Specific T Regulatory Type 1 Cells. Front Immunol (2018) 9:682. doi: 10.3389/fimmu.2018.00682

157. Kryczanowsky F, Raker V, Graulich E, Domogalla MP, Steinbrink K. Il-10Modulated Human Dendritic Cells for Clinical Use: Identification of a Stable and Migratory Subset With Improved Tolerogenic Activity. J Immunol (2016) 197(9):3607-17. doi: 10.4049/jimmunol.1501769

158. Song S, Yuan P, Wu H, Chen J, Fu J, Li P, et al. Dendritic Cells With an Increased PD-L1 by TGF- $\beta$ Induce T Cell Anergy for the Cytotoxicity of Hepatocellular Carcinoma Cells. Int Immunopharmacol (2014) 20(1):11723. doi: 10.1016/j.intimp.2014.02.027

159. Qian C, Qian L, Yu Y, An H, Guo Z, Han Y, et al. Fas Signal Promotes the Immunosuppressive Function of Regulatory Dendritic Cells Via the ERK/ $\beta$ Catenin Pathway. J Biol Chem (2013) 288(39):27825-35. doi: 10.1074/ jbc.M112.425751

160. Lopes DM, Oliveira SC, Page B, Carvalho LP, Carvalho EM, Cardoso LS. Schistosoma Mansoni Rsm29 Antigen Induces a Regulatory Phenotype on Dendritic Cells and Lymphocytes From Patients With Cutaneous Leishmaniasis. Front Immunol (2018) 9:3122. doi: 10.3389/fimmu.2018.03122

161. Luan YY, Zhang L, Zhu FJ, Dong N, Lu JY, Yao YM. Effect of TIPE1 on Immune Function of Dendritic Cells and Its Signaling Pathway in Septic Mice. J Infect Dis (2019) 220(4):699-709. doi: 10.1093/infdis/jiz158

162. Xu Y, Tang X, Yang M, Zhang S, Li S, Chen Y, et al. Interleukin 10 GeneModified Bone Marrow-Derived Dendritic Cells Attenuate Liver Fibrosis in Mice by Inducing Regulatory T Cells and Inhibiting the TGF- $\beta / S$ mad 
Signaling Pathway. Mediators Inflammation (2019) 2019:4652596. doi: $10.1155 / 2019 / 4652596$

163. Lan Z, Ge W, Arp J, Jiang JF, Liu WH, Gordon D, et al. Induction of Kidney Allograft Tolerance by Soluble Cd83 Associated With Prevalence of Tolerogenic Dendritic Cells and Indoleamine 2,3-Dioxygenase. Transplantation (2010) 90(12):1286-93. doi: 10.1097/TP.0b013e3182007bbf

164. Trabanelli S, Lecciso M, Salvestrini V, Cavo M, Očadlíková D, Lemoli RM, et al. PGE2-Induced IDO1 Inhibits the Capacity of Fully Mature DCs to Elicit an In Vitro Antileukemic Immune Response. J Immunol Res (2015) 2015:253191. doi: 10.1155/2015/253191

165. Flórez-Grau G, Cabezón R, Borgman KJE, España C, Lozano JJ, GarciaParajo MF, et al. Up-Regulation of EP(2) and EP(3) Receptors in Human Tolerogenic Dendritic Cells Boosts the Immunosuppressive Activity of PGE (2). J Leukoc Biol (2017) 102(3):881-95. doi: 10.1189/jlb.2A1216-526R

166. Turnquist HR, Raimondi G, Zahorchak AF, Fischer RT, Wang Z, Thomson AW. Rapamycin-Conditioned Dendritic Cells are Poor Stimulators of Allogeneic CD4+ T Cells, But Enrich for Antigen-Specific Foxp3+ T Regulatory Cells and Promote Organ Transplant Tolerance. J Immunol (2007) 178(11):7018-31. doi: 10.4049/jimmunol.178.11.7018

167. Campos-Acuña J, Pérez F, Narváez E, Campos-Mora M, Gajardo T, Catalán D, et al. Rapamycin-Conditioned Dendritic Cells Activated With Monophosphoryl Lipid-a Promote Allograft Acceptance In Vivo. Immunotherapy (2015) 7(2):101-10. doi: 10.2217/imt.14.116

168. Kim SH, Moon JH, Jeong SU, Jung HH, Park CS, Hwang BY, et al. Induction of Antigen-Specific Immune Tolerance Using Biodegradable Nanoparticles Containing Antigen and Dexamethasone. Int J Nanomed (2019) 14:5229-42. doi: $10.2147 / \mathrm{ijn} . S 210546$

169. Jauregui-Amezaga A, Cabezón R, Ramírez-Morros A, España C, Rimola J, Bru C, et al. Intraperitoneal Administration of Autologous Tolerogenic Dendritic Cells for Refractory Crohn's Disease: A Phase I Study. J Crohns Colitis (2015) 9(12):1071-8. doi: 10.1093/ecco-jcc/jjv144

170. Bell GM, Anderson AE, Diboll J, Reece R, Eltherington O, Harry RA, et al. Autologous Tolerogenic Dendritic Cells for Rheumatoid and Inflammatory Arthritis. Ann Rheum Dis (2017) 76(1):227-34. doi: 10.1136/annrheumdis2015-208456

171. Harry RA, Anderson AE, Isaacs JD, Hilkens CM. Generation and Characterisation of Therapeutic Tolerogenic Dendritic Cells for Rheumatoid Arthritis. Ann Rheum Dis (2010) 69(11):2042-50. doi: 10.1136/ard.2009.126383

172. Zhang M, Zheng Y, Sun Y, Li S, Chen L, Jin X, et al. Knockdown of NEAT1 Induces Tolerogenic Phenotype in Dendritic Cells by Inhibiting Activation of NLRP3 Inflammasome. Theranostics (2019) 9(12):3425-42. doi: 10.7150/ thno. 33178

173. Wu J, Zhang H, Zheng Y, Jin X, Liu M, Li S, et al. The Long Noncoding RNA Malat1 Induces Tolerogenic Dendritic Cells and Regulatory T Cells Via Mir155/Dendritic Cell-Specific Intercellular Adhesion Molecule-3 Grabbing Nonintegrin/Il10 Axis. Front Immunol (2018) 9:1847. doi: 10.3389/ fimmu.2018.01847

174. Zhang X, Li M, Lian D, Zheng X, Zhang ZX, Ichim TE, et al. Generation of Therapeutic Dendritic Cells and Regulatory T Cells for Preventing Allogeneic Cardiac Graft Rejection. Clin Immunol (2008) 127(3):313-21. doi: 10.1016/j.clim.2008.01.013

175. Pearce EL, Pearce EJ. Metabolic Pathways in Immune Cell Activation and Quiescence. Immunity (2013) 38(4):633-43. doi: 10.1016/j.immuni.2013.04.005

176. Thwe PM, Pelgrom LR, Cooper R, Beauchamp S, Reisz JA, D'Alessandro A, et al. Cell-Intrinsic Glycogen Metabolism Supports Early Glycolytic Reprogramming Required for Dendritic Cell Immune Responses. Cell Metab (2017) 26(3):558-67.e5. doi: 10.1016/j.cmet.2017.08.012

177. Guak H, Al Habyan S, Ma EH, Aldossary H, Al-Masri M, Won SY, et al. Glycolytic Metabolism is Essential for CCR7 Oligomerization and Dendritic Cell Migration. Nat Commun (2018) 9(1):2463. doi: 10.1038/s41467-01804804-6

178. Everts B, Amiel E, Huang SC, Smith AM, Chang CH, Lam WY, et al. TLRDriven Early Glycolytic Reprogramming Via the Kinases TBK1-IKKe Supports the Anabolic Demands of Dendritic Cell Activation. Nat Immunol (2014) 15(4):323-32. doi: 10.1038/ni.2833

179. Gotoh K, Morisaki T, Setoyama D, Sasaki K, Yagi M, Igami K, et al. Mitochondrial P32/C1qbp Is a Critical Regulator of Dendritic Cell
Metabolism and Maturation. Cell Rep (2018) 25(7):1800-15.e4. doi: 10.1016/j.celrep.2018.10.057

180. Holtzhausen A, Zhao F, Evans KS, Tsutsui M, Orabona C, Tyler DS, et al. Melanoma-Derived Wnt5a Promotes Local Dendritic-Cell Expression of IDO and Immunotolerance: Opportunities for Pharmacologic Enhancement of Immunotherapy. Cancer Immunol Res (2015) 3(9):1082-95. doi: 10.1158/ 2326-6066.Cir-14-0167

181. Ferreira GB, Vanherwegen AS, Eelen G, Gutiérrez ACF, Van Lommel L, Marchal K, et al. Vitamin D3 Induces Tolerance in Human Dendritic Cells by Activation of Intracellular Metabolic Pathways. Cell Rep (2015) 10 (5):711-25. doi: 10.1016/j.celrep.2015.01.013

182. Everts B, Amiel E, van der Windt GJ, Freitas TC, Chott R, Yarasheski KE, et al. Commitment to Glycolysis Sustains Survival of NO-producing Inflammatory Dendritic Cells. Blood (2012) 120(7):1422-31. doi: 10.1182/ blood-2012-03-419747

183. Wei HJ, Gupta A, Kao WM, Almudallal O, Letterio JJ, Pareek TK. Nrf2mediated Metabolic Reprogramming of Tolerogenic Dendritic Cells is Protective Against Aplastic Anemia. J Autoimmun (2018) 94:33-44. doi: 10.1016/j.jaut.2018.07.005

184. Sun Y, Oravecz-Wilson K, Bridges S, McEachin R, Wu J, Kim SH, et al. miR142 Controls Metabolic Reprogramming That Regulates Dendritic Cell Activation. J Clin Invest (2019) 129(5):2029-42. doi: 10.1172/jci123839

185. Mogilenko DA, Haas JT, L'Homme L, Fleury S, Quemener S, Levavasseur M, et al. Metabolic and Innate Immune Cues Merge Into a Specific Inflammatory Response Via the UPR. Cell (2019) 177(5):1201-16.e19. doi: 10.1016/j.cell.2019.03.018

186. Romero MM, Duarte A, Pastorini M, Alemán M. Role of $\alpha$-Glucan-Induced Oxygen Species in Dendritic Cells and its Impact in Immune Response Against Tuberculosis. Int J Med Microbiol (2019) 309(6):151328. doi: 10.1016/j.ijmm.2019.07.002

187. Oberkampf M, Guillerey C, Mouriès J, Rosenbaum P, Fayolle C, Bobard A, et al. Mitochondrial Reactive Oxygen Species Regulate the Induction of CD8 (+) T Cells by Plasmacytoid Dendritic Cells. Nat Commun (2018) 9(1):2241. doi: 10.1038/s41467-018-04686-8

188. Woltman AM, van der Kooij SW, Coffer PJ, Offringa R, Daha MR, van Kooten C. Rapamycin Specifically Interferes With GM-CSF Signaling in Human Dendritic Cells, Leading to Apoptosis Via Increased p27KIP1 Expression. Blood (2003) 101(4):1439-45. doi: 10.1182/blood-2002-06-1688

189. Perl A. mTOR Activation is a Biomarker and a Central Pathway to Autoimmune Disorders, Cancer, Obesity, and Aging. Ann N Y Acad Sci (2015) 1346(1):33-44. doi: 10.1111/nyas.12756

190. Tomić S, Janjetović K, Mihajlović D, Milenković M, Kravić-Stevović T, Marković Z, et al. Graphene Quantum Dots Suppress Proinflammatory T Cell Responses Via Autophagy-Dependent Induction of Tolerogenic Dendritic Cells. Biomaterials (2017) 146:13-28. doi: 10.1016/j.biomaterials.2017.08.040

191. Watson AR, Dai H, Zheng Y, Nakano R, Giannou AD, Menk AV, et al. Mtorc2 Deficiency Alters the Metabolic Profile of Conventional Dendritic Cells. Front Immunol (2019) 10:1451. doi: 10.3389/fimmu.2019.01451

192. Liu Y, Tong L, Luo Y, Li X, Chen G, Wang Y. Resveratrol Inhibits the Proliferation and Induces the Apoptosis in Ovarian Cancer Cells Via Inhibiting Glycolysis and Targeting AMPK/mTOR Signaling Pathway. J Cell Biochem (2018) 119(7):6162-72. doi: 10.1002/jcb.26822

193. Wculek SK, Khouili SC, Priego E, Heras-Murillo I, Sancho D. Metabolic Control of Dendritic Cell Functions: Digesting Information. Front Immunol (2019) 10:775. doi: 10.3389/fimmu.2019.00775

194. Kelly B, O'Neill LA. Metabolic Reprogramming in Macrophages and Dendritic Cells in Innate Immunity. Cell Res (2015) 25(7):771-84. doi: 10.1038/cr.2015.68

195. Bhandari T, Olson J, Johnson RS, Nizet V. Hif-1 $\alpha$ Influences Myeloid Cell Antigen Presentation and Response to Subcutaneous OVA Vaccination. J Mol Med (Berl) (2013) 91(10):1199-205. doi: 10.1007/s00109-013-1052-y

196. Thwe PM, Fritz DI, Snyder JP, Smith PR, Curtis KD, O’Donnell A, et al. SykDependent Glycolytic Reprogramming in Dendritic Cells Regulates IL-1 $\beta$ Production to $\beta$-Glucan Ligands in a TLR-independent Manner. J Leukoc Biol (2019) 106(6):1325-35. doi: 10.1002/jlb.3a0819-207rr

197. Bode K, Bujupi F, Link C, Hein T, Zimmermann S, Peiris D, et al. Dectin-1 Binding to Annexins on Apoptotic Cells Induces Peripheral Immune Tolerance Via NADPH Oxidase-2. Cell Rep (2019) 29(13):4435-46.e9. doi: 10.1016/j.celrep.2019.11.086 
198. Mitchell S, Vargas J, Hoffmann A. Signaling Via the Nfkb System. Wiley Interdiscip Rev Syst Biol Med (2016) 8(3):227-41. doi: 10.1002/wsbm.1331

199. Rescigno M, Martino M, Sutherland CL, Gold MR, Ricciardi-Castagnoli P. Dendritic Cell Survival and Maturation are Regulated by Different Signaling Pathways. J Exp Med (1998) 188(11):2175-80. doi: 10.1084/jem.188.11.2175

200. Jackson SH, Yu CR, Mahdi RM, Ebong S, Egwuagu CE. Dendritic Cell Maturation Requires STAT1 and is Under Feedback Regulation by Suppressors of Cytokine Signaling. J Immunol (2004) 172(4):2307-15. doi: 10.4049/jimmunol.172.4.2307

201. Xu L, Zhang Y, Tian K, Chen X, Zhang R, Mu X, et al. Apigenin Suppresses PD-L1 Expression in Melanoma and Host Dendritic Cells to Elicit Synergistic Therapeutic Effects. J Exp Clin Cancer Res (2018) 37(1):261. doi: 10.1186/s13046-018-0929-6

202. Zhu J, Yao K, Guo J, Shi H, Ma L, Wang Q, et al. miR-181a and miR-150 Regulate Dendritic Cell Immune Inflammatory Responses and Cardiomyocyte Apoptosis Via Targeting JAK1-STAT1/c-Fos Pathway. J Cell Mol Med (2017) 21(11):2884-95. doi: 10.1111/jcmm.13201

203. Xu J, Lee MH, Chakhtoura M, Green BL, Kotredes KP, Chain RW, et al. Stat2 Is Required for TLR-Induced Murine Dendritic Cell Activation and CrossPresentation. J Immunol (2016) 197(1):326-36. doi: 10.4049/jimmunol.1500152

204. Melillo JA, Song L, Bhagat G, Blazquez AB, Plumlee CR, Lee C, et al. Dendritic Cell (DC)-Specific Targeting Reveals Stat3 as a Negative Regulator of DC Function. J Immunol (2010) 184(5):2638-45. doi: 10.4049/ jimmunol.0902960

205. Bazhin AV, von Ahn K, Fritz J, Werner J, Karakhanova S. Interferon- $\alpha$ UpRegulates the Expression of PD-L1 Molecules on Immune Cells Through
STAT3 and p38 Signaling. Front Immunol (2018) 9:2129. doi: 10.3389/ fimmu.2018.02129

206. Toniolo PA, Liu S, Yeh JE, Moraes-Vieira PM, Walker SR, Vafaizadeh V, et al. Inhibiting STAT5 by the BET Bromodomain Inhibitor JQ1 Disrupts Human Dendritic Cell Maturation. J Immunol (2015) 194(7):3180-90. doi: 10.4049/jimmunol.1401635

207. Zhu HC, Qiu T, Liu XH, Dong WC, Weng XD, Hu CH, et al. Tolerogenic Dendritic Cells Generated by RelB Silencing Using shRNA Prevent Acute Rejection. Cell Immunol (2012) 274(1-2):12-8. doi: 10.1016/ j.cellimm.2012.02.012

208. Benham H, Nel HJ, Law SC, Mehdi AM, Street S, Ramnoruth N, et al. Citrullinated Peptide Dendritic Cell Immunotherapy in HLA Risk Genotype-Positive Rheumatoid Arthritis Patients. Sci Transl Med (2015) 7 (290):290ra87. doi: 10.1126/scitranslmed.aaa9301

Conflict of Interest: The authors declare that the research was conducted in the absence of any commercial or financial relationships that could be construed as a potential conflict of interest.

Copyright (c) 2021 Lin, Wang, Liu, Cheng, Deng, Zhu and Chen. This is an openaccess article distributed under the terms of the Creative Commons Attribution License (CC BY). The use, distribution or reproduction in other forums is permitted, provided the original author(s) and the copyright owner(s) are credited and that the original publication in this journal is cited, in accordance with accepted academic practice. No use, distribution or reproduction is permitted which does not comply with these terms. 